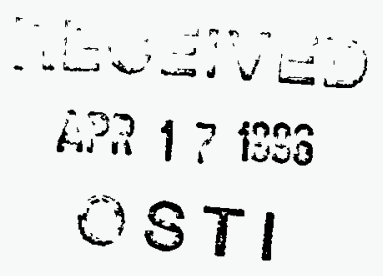

Summary of Treatment, Storage, and Disposal Facility Usage Data Collection from U.S. Department of Energy Sites

Radioactive Waste

Technical Support Program

April 1995 

This report was prepared as an account of work sponsored by an agency of the United States Government. Neither the United States Government nor any agency thereof, nor any of their employees, makes any warranty, express or implied, or assumes any legal liability or responsibility for the accuracy, completeness, or usefulness of any information, apparatus, product, or process disclosed, or represents that its use would not infringe privately owned rights. Reference herein to any specific commercial product, process, or service by trade name, trademark, manufacturer, or otherwise does not necessarily constitute or imply its endorsement, recommendation, or favoring by the United States Government or any agency thereof. The views and opinions of authors expressed herein do not necessarily state or reflect those of the United States Government or any agency thereof.

\title{
Summary of Treatment, Storage, and Disposal Facility Usage Data Collected from U.S. Department of Energy Sites
}

\author{
Andy Jacobs (Lockheed Idaho, RWTSP) \\ Kyle Oswald (Lockheed Idaho, RWTSP) \\ Carl Trump (EG\&G Rocky Flats)
}

April 1995

\author{
Idaho National Engineering Laboratory \\ Lockheed Idaho Technologies Company \\ Radioactive Waste Technical Support Program \\ Idaho Falls, Idaho 83415
}

Prepared for the

U.S. Department of Energy

Assistant Secretary for Environmental Management

Under DOE Idaho Operations Office

Contract DE-AC07-94ID13223 


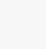




\begin{abstract}
This report presents an analysis for the U.S. Department of Energy (DOE) to determine the level and extent of treatment, storage, and disposal facility (TSDF) assessment duplication.

Commercial TSDFs are used as an integral part of the hazardous waste management process for those DOE sites that generate hazardous waste. Data regarding the DOE sites' usage have been extracted from three sets of data and analyzed in this report. The data are presented both qualitatively and quantitatively, as appropriate. This information provides the basis for further analysis of assessment duplication to be documented in issue papers as appropriate. Once the issues have been identified and adequately defined, corrective measures will be proposed and subsequently implemented.
\end{abstract}




\section{CONTENTS}

ABSTRACT $\ldots \ldots \ldots \ldots \ldots \ldots \ldots \ldots \ldots \ldots \ldots \ldots \ldots \ldots \ldots \ldots \ldots$

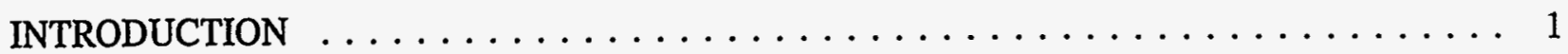

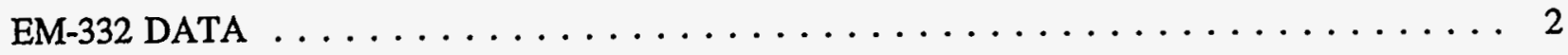

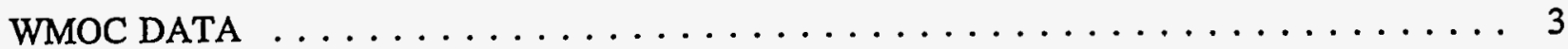

DERIVING COST DATA FOR PERFORMING TSDF ASSESSMENTS $\ldots \ldots \ldots \ldots$

WMS DATA AND THE CONSOLIDATED (INEL) EFFORT $\ldots \ldots \ldots \ldots \ldots \ldots$

CONCLUSION $\ldots \ldots \ldots \ldots \ldots \ldots \ldots \ldots \ldots \ldots \ldots \ldots \ldots \ldots \ldots$

Appendix A-Raw Data from EM-332, WMOC, and WMS (SMAC) . . . . . . . . A A-1

\section{TABLES}

1. Roll-up of WMS data $\ldots \ldots \ldots \ldots \ldots \ldots \ldots \ldots \ldots \ldots \ldots \ldots$ 



\section{Summary of Treatment, Storage, and Disposal Facility Usage Data Collected from U.S. Department of Energy Sites}

\section{INTRODUCTION}

Commercial treatment, storage, and disposal facilities (TSDFs) are used as an integral part of the hazardous waste management process for many U.S. Department of Energy (DOE) sites that generate hazardous waste. Information regarding the DOE sites' usage of these TSDFs has been organized into three data sets. This report compiles and analyzes the three data sets, which include the following:

- U.S. Department of Energy Headquarters (DOE-HQ) EM-332 data

- DOE Waste Management Operations Committee (WMOC) data

- Waste Manifest System (WMS) data.

Each data set is analyzed and presented in terms of individual TSDFs used by the sites in order to determine which TSDFs have duplicative usage. The duplication-of-use information is important because existing DOE orders and best management practices drive individual DOE sites to perform an environmental safety and health (ES\&H) assessment of the TSDFs with which they. subcontract. ${ }^{a}$ Because more than one DOE site may subcontract with the same TSDF, the potential for duplicating assessments exists. Therefore, data that show duplication of usage also represent the potential number of duplicated assessments performed by DOE complex wide. By analyzing and compiling the data in this manner, a cost-saving potential can be calculated based upon the elimination of the duplicated assessments. A summary of the raw data is located in Appendix A.

Two of the data sets, EM-332 and WMOC, contained cost information for performing TSDF assessments along with the site usage data. The third data set, WMS, does not include any cost information. However, the costs associated with performing these assessments reported in the data are inconsistent from site to site around the DOE complex since standard assessment criteria

a. $10 \mathrm{CFR} 830$ requires that procured items and services meet established requirements and perform as specified. Prospective suppliers must be evaluated and selected on the basis of specified criteria.

Department of Energy Acquisition Requirements (DEARS), 48 CFR 970, requires compliance with regulations promulgated by the U.S. Environmental Protection Agency (EPA), DOE, U.S. Department of Transportation (DOT), Executive Orders, etc.

DOE-HQ Order 5480.1B requires that contractors ensure that proposed subcontractors operate in compliance with ES\&H regulations and requirements.

DOE-HQ Order 5482.1B requires that maintenance and operation $(M \& O)$ contractors ensure that all subcontractors operating under the $M \& O$ subcontract do so in accordance with ES\&H regulations and requirements. This would include subcontractors to the prime M\&O contractors. 
have not been established. Therefore, baseline information on TSDF assessments was collected and used to determine an approximate cost for the WMS data duplications and future cost savings.

\section{EM-332 DATA}

The EM-332 Hazardous Waste Program Manager collected data regarding the use of TSDFs by DOE sites and the costs of conducting TSDF assessments from operations offices and provided the data to the Radioactive Waste Technical Support Program (TSP, Lockheed Idaho Technologies Company) for analysis. All DOE operations offices received a request from the DOE-HQ EM-332 Hazardous Waste Program Manager for information about TSDF usage for sites within their purview. Seven DOE operations offices responded with data from 11 sites. Approximately 33 sites could have responded.

A large amount of data received from the sites was incomplete, especially with regard to the costs associated with conducting TSDF assessments. The incomplete cost data could represent the difficulty the sites experienced in trying to estimate the costs of conducting assessments, or it could simply mean that assessments were not conducted. The reported costs of some TSDF assessments were extremely low. This raised doubts as to the adequacy of such assessments and the soundness of the acceptance criteria.

The average cost of assessments conducted by the reporting sites was $\$ 7,558$. This average considers only those values reported by the sites and does not include blank data. If the cost data were not provided by the site, it was assumed that an assessment was not conducted, for the purpose of calculating the average assessment cost. The 11 sites reported using 86 unique TSDFs via 142 separate subcontracts throughout the two-year period from the beginning of FY 1993 until the end of FY 1994. Twenty-eight of the reported contractual usages had no associated assessment costs reported. This was left blank, rather than being reported as zero.

The submitted data reveal the following information:

- A total of 86 unique TSDFs were used by the 11 reporting sites

- The total number of assessments conducted by the 11 reporting sites was 110 out of 142 TSDF subcontracts

- $\quad 58$ TSDFs had only one DOE site subcontract

- 28 TSDFs had two or more DOE site subcontracts, for a total of 84 contracts

- Contractual usage duplication was $56^{\mathrm{b}}$

b. Total subcontracts $(142)$ - number of unique TSDFs used $(86)=56$ duplicated usages. 
- Of the 28 TSDFs with multiple DOE usage, 76 assessments were conducted, $48^{\mathrm{c}}$ of which were duplicated; out of the 84 contractual usages, 8 assessments were not conducted (i.e., no cost information was provided)

- $44 \%$ of TSDF assessments performed by the sites were duplicated.

The cost to perform an assessment should, at least, exceed $\$ 1,500$ when considering both travel cost and personnel time involved with performing an assessment and documenting the results. If assessments costing less than $\$ 1,500$ are considered not suitably effective in significantly reducing long-term liability, then the following conclusion may be drawn:

- The number of TSDF assessments performed by the sites at a cost of less than $\$ 1,500$ (10 assessments), and the number of TSDFs subcontracted by the sites but not assessed (32 TSDF subcontracts with no assessment) equals 42 . Therefore, $30 \%{ }^{\mathrm{e}}$ of TSDFs are not suitably assessed by the sites.

An immediate cost savings of approximately $\$ 360,000^{\mathrm{f}}$ would result from eliminating the duplicate assessments currently being conducted by these 11 reporting sites. This savings could be expected over a two-year period, since that is the timeframe represented by the data.

The cost savings assumption can be taken one step further by projecting the duplication to those sites that did not report data. Taking this additional step is valid if data from sites that reported are representative of the whole (all sites), at least in the context of assessment cost and TSDF usage. Currently, no reason exists to draw conclusions to the contrary. Taking 33 as the total number of sites that could have reported and increasing the number of duplicate assessments proportionally yields a total of 144 duplicated assessments that would be performed by the 33 sites. The resulting potential cost savings would then be approximately $\$ 1.09$ million $^{\mathrm{g}}$ over a twoyear period.

\section{WMOC DATA}

The DOE WMOC has also collected hazardous waste TSDF usage information from its member sites. Approximately 18 sites participate on the WMOC and were asked for specific data

c. Assessments (76) - TSDFs with multiple site subcontracts $(28)=48$ duplicated assessments.

d. Number of duplicated assessments $(48) \div$ total number of assessments $(110) \times 100=44 \%$ of TSDF assessments were duplicated.

e. Number of unsuitable assessments (42) + total number of subcontracts (142) $\times 100=30 \%$ of TSDFs are not suitably assessed.

f. Number of duplicated assessments (48) $\mathrm{x}$ average assessment cost $(\$ 7,558)=\$ 362,784$ cost savings expected from elimination of duplicative assessments.

g. Number of projected duplicated assessments $(144) \times$ average assessment cost $(\$ 7,558)=\$ 1.09$ million cost savings expected through elimination of duplicative assessments. 
relative to their hazardous waste TSDF usages. Information on TSDFs used by the member sites was collected. Fifteen of the 18 member sites responded. The information revealed the following:

- The 15 reporting WMOC sites used 153 unique TSDFs. No time period was specified relative to the reported data.

- The 15 sites reported 272 contractual usages of the 153 TSDFs.

- Duplicate use occurred in $119^{\mathrm{h}}$ out of 272 usages by the 15 reporting WMOC sites. $44 \%{ }^{i}$ of potential assessments were duplicate assessments.

If the collected WMOC data are representative of 33 DOE sites, then the following projections can be made:

- $\quad$ The number of TSDFs projected to be used by all 33 sites is $337^{j}$

- The number of duplicated contractual usages associated with using 337 TSDFs is $263 .^{k}$

Cost information for assessments being conducted by the WMOC sites that reported indicates that assessments budgeted and scheduled will cost $\$ 1,141,720$ for 96 contractual usages.

- This reduces to an average assessment cost of $\$ 11,893$ per assessment ${ }^{1}$ of a TSDF

- $35 \%^{\mathrm{m}}$ of TSDF contractual usages receive an assessment; $65 \%$ do not.

Duplicate use becomes important when considering the potential for duplicated assessments, since each TSDF usage in this case represents the possibility that an assessment was conducted in accordance with the requirements to ensure that ES\&H goals and objectives are being met by subcontractors. To perform cost calculations beyond this point, it is necessary to assume a cost

h. Total number of subcontracts (272) - total number of unique TSDFs (153) $=119$ duplicated usages.

i. Number duplicated (119) $\div$ total number of subcontracts (272) $\times 100=44 \%$ of assessments were duplicated.

j. Number of TSDFs (153) $\div$ number of WMOC sites $(15)=x \div$ total number of DOE sites (33); $x=337$ TSDFs used by 33 sites.

k. The number of duplicated TSDF contractual usages out of a field of 153 is 119 . The duplicated usage potential is therefore equal to $119 \div 153=0.78$, and 337 (number of TSDFs used) $x 0.78$ (duplicated usage potential) $=263$ duplicated usages.

1. Total cost of assessments $(\$ 1,141,720)+$ number of assessments $(96)=\$ 11,893$ per assessment conducted.

m. Number of TSDFs assessed $(96) \div$ total number of TSDF subcontracts $(272) \times 100=35 \%$ of contractual usages receive an assessment. 
value for performing TSDF assessments. The WMOC data indicate an average of $\$ 11,893$ to perform a TSDF assessment. If an assessment were conducted for each TSDF usage, then the additional cost to perform duplicate assessments would be calculated as equal to $\$ 3.1$ million. ${ }^{\text {n }}$ Therefore, by eliminating duplicate assessments, approximately $\$ 3.1$ million could be saved. It is not known over what time period this would occur, since the usage data have no specified time boundaries.

\section{DERIVING COST DATA FOR PERFORMING TSDF ASSESSMENTS}

Deriving cost data to calculate cost savings must be performed and interpreted within the proper context. Spending on TSDF assessments varies from site to site around the DOE complex, largely as a result of the lack of specified assessment criteria. Currently, there is no way of measuring the adequacy of the assessments being performed, because there is a lack of established complex-wide assessment criteria. As sites perform assessments to differing criteria, it is expected that the associated costs will differ.

Baseline information about assessment protocols does exist. The Idaho National Engineering Laboratory (INEL) is the lead laboratory for a consortium involved with consolidated assessment/contracting for TSDF use at DOE sites with an EG\&G, Inc., subsidiary as the M\&O contractor. As a result of the focused purpose and clear understanding of the assessment effort, the consolidated effort performs the most comprehensive assessment approach currently used anywhere in the DOE waste management system. The cost for TSDF assessments performed by this approach is approximately $\$ 53,000$ per TSDF annual assessment. The average of $\$ 53,000$ is derived from the INEL work package document that details the steps and associated resources required to complete the assessment scope of work for the consortium. The INEL technical lead project manager assigned to the effort developed the work package. Assessment preparation time and required participant training are included as part of the TSDF assessment cost.

The cost is equally divided among the INEL-led consortium participants. If the number of participants were to increase as a result of expanding the effort to $33 \mathrm{DOE}$ sites, then the cost to each site would be approximately $\$ 1,619 /$ site. $^{\circ}$ This is $79 \%$ less to perform consolidated TSDF assessments when compared to the average assessment cost of $\$ 7,558$ presented in the EM-332 data section, and $86 \%$ less when compared to the WMOC average of $\$ 11,893$ per assessment.

TSDF assessment protocols were established by the INEL-led consortium for conducting the TSDF consolidated assessments in order that consolidated hazardous waste disposal subcontracts could be put into place. Consortium members conduct assessments to ensure that potential TSDF subcontractors are meeting ES\&H goals and objectives before awarding a subcontract. It is therefore prudent to base costs associated with TSDF assessments upon this already established baseline.

n. Number of projected duplicated assessments (263) $x$ average WMOC audit cost $(\$ 11,893)=\$ 3.1$ million to perform duplicated assessments.

o. Average consortium TSDF assessment cost $(\$ 53,416) \div$ number of sites $(33)=\$ 1,619 /$ site 
Sites that did not provide assessment cost information for particular TSDFs are most likely not performing an assessment. Additionally, cost data from some sites indicated that an extremely low amount had been spent performing some assessments. This may indicate that the criteria to which the assessment were conducted were less stringent than those of the consortium. A review of assessment criteria provided by some of the reporting sites confirms this suspicion.

A reduction in the number of TSDF usages may be expected from a consolidated assessment approach for two reasons. First, the duplicate usage is eliminated along with the need to conduct multiple assessments on a single TSDF. Second, the actual number of TSDFs used by the complex will decrease. Before implementing a consolidated approach to assessments, a complexwide TSDF needs analysis will be performed to determine the complex's hazardous waste TSDF needs. This is the approach that was taken by the INEL-led consortium. Before joint assessments/contracting occurred, it was first necessary to determine the participants' needs relative to hazardous waste treatment, storage, and disposal. The result was an overall reduction in the number of TSDFs the consolidated participants used over what they had been using individually. Reducing this difference through implementation of a consolidated approach will result in additional cost savings since the number of TSDFs requiring assessments will subsequently decrease. The exact number of TSDFs that would be required to meet the complex's needs is not known, since a needs analysis has not yet been performed. If, however, the number of TSDFs used by the DOE complex were reduced by 50 , the cost savings from a reduction in the number of assessments required would be $\$ 377,900^{\circ}$; a reduction of 100 would amount to a savings of $\$ 755,800$. The timeframe during which these savings would be realized would parallel the assessment periodicity.

\section{WMS DATA AND THE CONSOLIDATED (INEL) EFFORT}

Data extracted from the WMS were also analyzed. The WMS is a subset of the data contained within the SMAC data system. Science Applications International Corporation (SAIC) maintains and operates the SMAC system for the DOE, Transportation Management Division (EM-261) under subcontract to Martin Marietta Energy Systems in Oak Ridge, Tennessee. The hazardous waste information contained in SMAC is based on the Uniform Hazardous Waste Shipping Manifests submitted to SAIC by each site. These manifests provide details regarding the date of shipment, the generator, and the specific TSDF taking custody of each individual shipment of waste. Data detailing DOE hazardous waste shipments from CY 1992 through CY 1994 were included in the analysis. From this information, a comprehensive TSDF use profile has been constructed to determine the number of unique TSDFs used by the complex per calendar year, the total number of TSDF subcontracts by each site per calendar year, and the number of duplicative contractual usages per calendar year.

Since the WMS data do not include costs for performing TSDF assessments, these costs had to be estimated. In order for sites to ensure compliance to ES\&H requirements by TSDF subcontractors, it is prudent for them to conduct assessments to the level of rigor performed by the INEL-led consortium. Therefore, it is prudent to base the cost of assessments performed by

p. Reduction in number of TSDFs (50) $x$ average EM-332 data assessment cost $(\$ 7,558)=\$ 377,900$ saved. 
the sites, and subsequent cost savings potential, on this established baseline. Further cost savings analysis related to the WMS data employs this approach.

The roll-up of the WMS data is presented in Table 1 and reveals the following information relative to TSDF usage for three years from CY 1992 through 1994 for a total of 39 DOE sites.

Assuming that the cost of compliance with ES\&H orders, policies, and guidelines will require resources of $\$ 53,416 / \mathrm{TSDF}$ assessment, the WMS data lead to the following conclusions and potential savings:

- $\quad 50 \%$ of TSDF subcontracts are duplicated

- If the duplicate assessments are eliminated through a consolidated assessment program, the cost savings would be approximately $\$ 7.1$ million $^{r}$ per calendar year

- If a consolidated TSDF subcontracting program is implemented, the total number of TSDFs required to meet the complex's needs drops considerably. If the total number of TSDFs required is 15 , then the cost savings would be approximately $\$ 6.3$ millions per calendar year

- Total cost savings expected from implementing a consolidated assessment and subcontracting program is $\$ 13.4$ million ( $\$ 7.1$ million $+\$ 6.3$ million) per calendar year.

Table 1. Roll-up of WMS data.

\begin{tabular}{cccc}
\hline Calendar year & TSDF subcontracts & Unique TSDFs used & Usage duplication \\
\hline 1992 & 238 & 128 & 110 \\
1993 & 265 & 131 & 134 \\
1994 & 261 & 124 & 137 \\
& $255=$ Avg. TSDF & 128 = Avg. unique & $127=$ Avg. TSDF \\
& subcontracts & TSDFs & duplication \\
\hline
\end{tabular}

q. Average TSDF duplication (127) $\div$ average number of TSDF contracts $(255) \times 100=50 \%$ of TSDF contracts are duplicated.

r. Average TSDF duplication (127) $\mathrm{x}$ average consolidated assessment cost $(\$ 53,416)=7.1$ million savings per calendar year.

S. Average consortium assessment cost $(\$ 53,416) \mathrm{x}$ [average number of unique TSDFs $(128)$ - total number of TSDFs required (15) $]=\$ 6.3$ million savings per year. 


\section{CONCLUSION}

It was the intention of those preparing this data report to present and analyze the data in an objective fashion allowing the data to speak for itself. Numerous conclusions could be reached using the data. From the start, it was the preparer's intention to focus on the duplication of TSDF usages in order to gain a perspective on the potential number of duplicative TSDF assessments being performed throughout the DOE complex. In order to place the duplication in perspective, associated assessment cost information was used, when available, to derive potential cost savings amounts for different possible scenarios.

The WMS data in this report are the best set in terms of ability to represent the TSDF duplication profile across the complex. This is because the data include all hazardous waste shipments to TSDFs by the sites broken down by calendar year. For this reason, formulation of options and recommendation relative to reducing the duplicate TSDF use should be based upon the WMS data set. Options for reducing the duplicate TSDF use will be presented in a separate issue report as appropriate. 


\section{Appendix A}

Raw Data from EM-332, WMOC, and WMS (SMAC) 


$$
\text { A-2 }
$$




\section{Appendix A}

\section{Raw Data from EM-332, WMOC, and WMS (SMAC)}

\section{SITE ACRONYM DEFINITIONS}

\begin{tabular}{ll}
\hline \multicolumn{1}{c}{ DOE Site } & \multicolumn{1}{c}{ Noun Name } \\
\hline ANLE & Argonne National Laboratory East \\
BNL & Brookhaven National Laboratory \\
INEL & Idaho National Engineering Laboratory \\
KCP & Kansas City Plant \\
LANL & Los Alamos National Laboratory \\
LLNL & Lawrence Livermore National Laboratory \\
MOUND & Mound \\
ORO & Oak Ridge (Y12, X10, K25) \\
Pinellas & Pinellas \\
REECO & Reynolds Electric Engineering Company \\
RFETS & Rocky Flats \\
RLO & Richland Operations \\
SNLA & Sandia National Laboratory Albuquerque \\
SNLL & Sandia National Laboratory Livermore \\
SRS & Savannah River Site \\
\hline
\end{tabular}


EM 332 Data sort by site

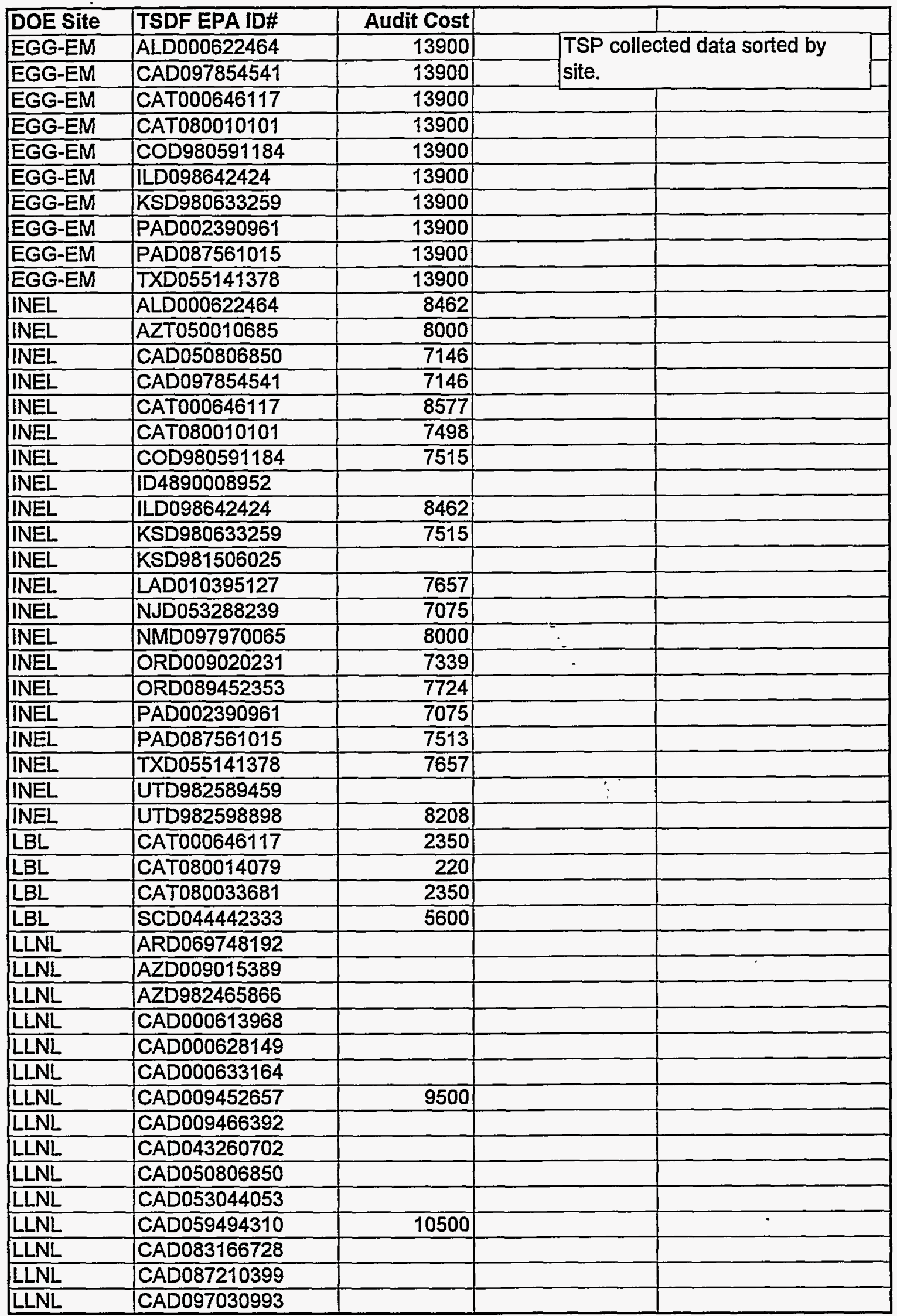


EM 332 Data sort by site

\begin{tabular}{|c|c|c|c|c|}
\hline LLNL & CAD980675276 & & & \\
\hline LLNL & CAD980883177 & & & \\
\hline LLNL & CAD980887418 & & & \\
\hline LLNL & CAD982042475 & & & \\
\hline$\overline{\text { LLNL }}$ & CAD990794133 & & & \\
\hline LLNL & CAL000027741 & & & \\
\hline LLNL & CAT000613968 & & & \\
\hline LLNL & KSD981506025 & & & \\
\hline LLNL & LAD981055791 & & & . \\
\hline LLNL & NCD000648451 & & & \\
\hline LLNL & NVD980895338 & & & \\
\hline$\overline{\text { LLNL }}$ & NYD048148175 & 12800 & & \\
\hline LLNL & PAD087561015 & 12800 & & \\
\hline LLNL & PAD981939846 & & & \\
\hline LLNL & TND000645770 & & & \\
\hline LLNL & TXD055141378 & 11600 & & \\
\hline LLNL & TXD982560294 & & & \\
\hline LLNL & UTD981552177 & & & \\
\hline LLNL & UTD991301748 & & & \\
\hline ORO & ALD046481032 & 10500 & & \\
\hline ORO & CEMENT KILN & 9500 & & \\
\hline ORO & KSD981506025 & 10500 & & \\
\hline ORO & KY-SLP-038.19 & 9600 & & \\
\hline ORO & KY-SLP-042.07 & 9600 & & \\
\hline ORO & LAD010395127 & 10500 & & \\
\hline ORO & Lasor Recycle & 8500 & & \\
\hline ORO & Nucycle Recycle & 8500 & & \\
\hline ORO & NVT330010000 & 10500 & & \\
\hline ORO & NYD986980233 & 10500 & & \\
\hline ORO & $\mathrm{OH} \mathrm{05-00-06}$ & 9600 & & \\
\hline ORO & $\mathrm{OH} \mathrm{66-00-03}$ & 9600 & & \\
\hline ORO & OHD053576294 & 9600 & & \\
\hline ORO & OHD053576294 & 10500 & & \\
\hline ORO & OHD981100969 & 9600 & & \\
\hline ORO & OHOIP004227*AD & 9600 & & \\
\hline ORO & OKD065438376 & 9600 & & \\
\hline ORO & RD\&D PERMIT & 10500 & & \\
\hline ORO & AZD983473539 & 10500 & & \\
\hline ORO & TND34692632 & 9500 & & \\
\hline ORO & TND932157570 & 15500 & & \\
\hline ORO & TND982109142 & 8500 & & \\
\hline ORO & TNOSNL011030160 & 10500 & & \\
\hline ORO & TXD055141378 & 10500 & & \\
\hline ORO & WVD988770673 & 9600 & & \\
\hline ORO & WVD988770673 & 9600 & & \\
\hline REECO & CAD050806850 & 2754 & & \\
\hline REECO & LAD010395127 & 3118 & & \\
\hline REECO & TXD055141378 & 3042 & & \\
\hline RFETS & ALD000622464 & 4395 & & \\
\hline RFETS & AZT050010685 & 4395 & & \\
\hline RFETS & CAD050806850 & 4395 & & \\
\hline
\end{tabular}


EM 332 Data sort by site

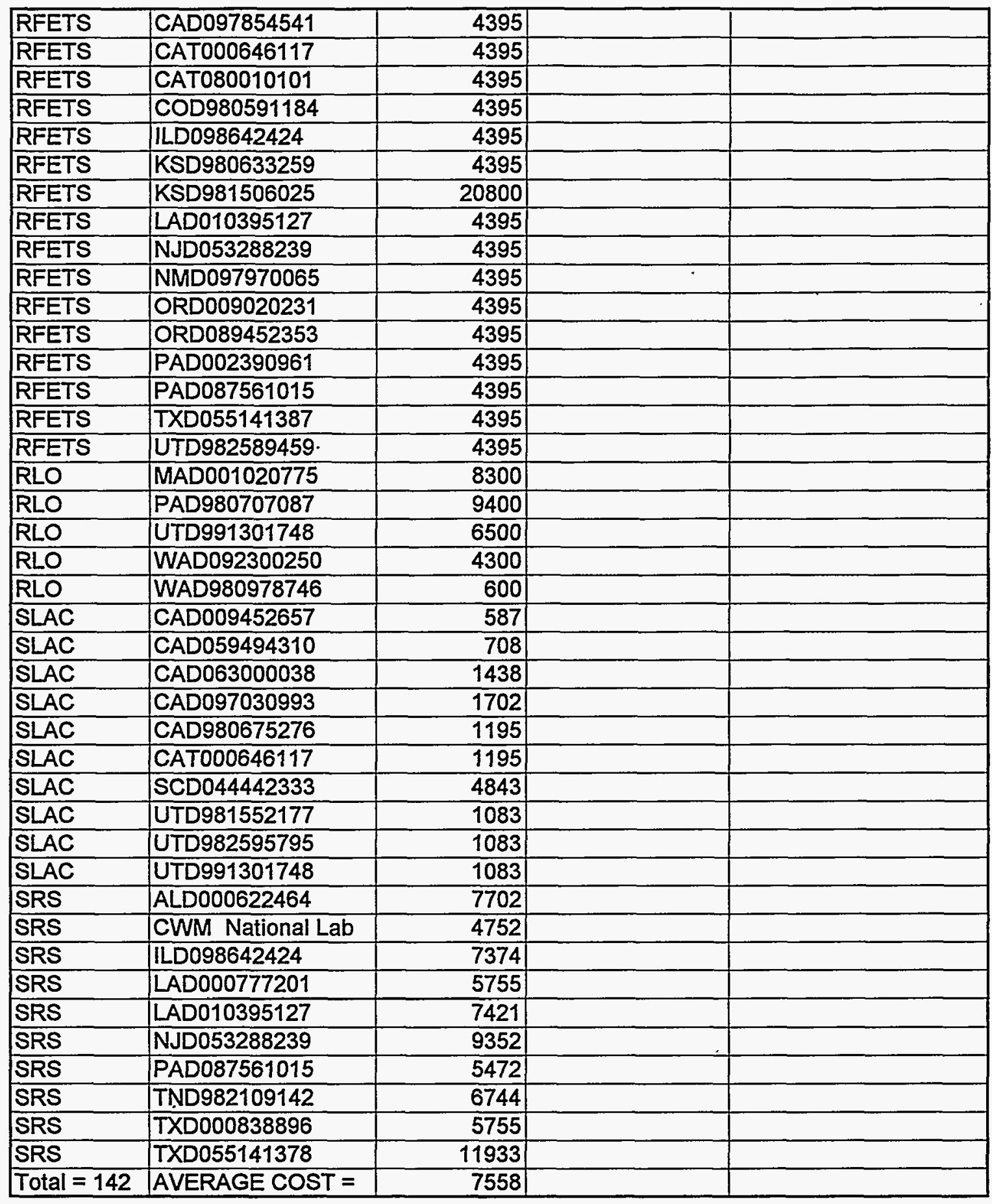


EM 332 Data sort by EPA ID\#

\begin{tabular}{|c|c|c|c|}
\hline DOE Site & TSDF EPA ID\# & Audit Cost & \\
\hline EGG-EM & ALD000622464 & 13900 & \multirow{3}{*}{$\begin{array}{l}\text { TSP collected data sorted by EPA } \\
\text { TSDF ID number. }\end{array}$} \\
\hline INEL & ALD000622464 & 8462 & \\
\hline RFETS & ALD000622464 & 4395 & \\
\hline SRS & ALD000622464 & 7702 & \\
\hline ORO & ALD046481032 & 10500 & \\
\hline LLNL & ARD069748192 & & \\
\hline LLNL & AZD009015389 & & \\
\hline LLNL & AZD982465866 & & \\
\hline$\overline{I N E L}$ & AZT050010685 & 8000 & \\
\hline RFETS & AZT050010685 & 4395 & . \\
\hline LLNL & CAD000613968 & & \\
\hline LLNL & CAD000628149 & & \\
\hline LLNL & CAD000633164 & & \\
\hline LLNL & CAD009452657 & 9500 & \\
\hline$\widehat{\text { SLAC }}$ & CAD009452657 & 587 & \\
\hline LLNL & CAD009466392 & & \\
\hline$\overline{\text { LLNL }}$ & CAD043260702 & & \\
\hline$\sqrt{\text { INEL }}$ & CAD050806850 & 7146 & \\
\hline LLNL & CAD050806850 & & \\
\hline REECO & CAD050806850 & 2754 & \\
\hline RFETS & CAD050806850 & 4395 & \\
\hline LLNL & CAD053044053 & & \\
\hline LLNL & CAD059494310 & 10500 & \\
\hline$\overline{\text { SLAC }}$ & CAD059494310 & 708 & \\
\hline SLAC & CAD063000038 & 1438 & \\
\hline LLNL & CAD083166728 & & \\
\hline LLNL & CAD087210399 & & \\
\hline LLNL & CAD097030993 & & \\
\hline SLAC & CAD097030993 & 1702 & \\
\hline EGG-EM & CAD097854541 & 13900 & \\
\hline INEL & CAD097854541 & 7146 & \\
\hline RFETS & CAD097854541 & 4395 & \\
\hline LLNL & CAD980675276 & & \\
\hline SLAC & CAD980675276 & 1195 & \\
\hline LLNL & CAD980883177 & & \\
\hline LLNL & CAD980887418 & & \\
\hline LLNL & CAD982042475 & & \\
\hline$\longdiv { \text { LLNL } }$ & CAD990794133 & & \\
\hline LLNL & CAL000027741 & & \\
\hline LLNL & CAT000613968 & & \\
\hline EGG-EM & CAT000646117 & 13900 & \\
\hline$\sqrt{\text { INEL }}$ & CAT000646117 & 8577 & \\
\hline LBL & CAT000646117 & 2350 & \\
\hline RFETS & CATO00646117 & 4395 & \\
\hline SLAC & CAT000646117 & 1195 & \\
\hline EGG-EM & САТ080010101 & 13900 & \\
\hline INEL & САТ080010101 & 7498 & \\
\hline RFETS & CAT080010101 & 4395 & \\
\hline LBL & CAT080014079 & 220 & \\
\hline$\overline{L B L}$ & САТ080033681 & 2350 & \\
\hline
\end{tabular}


EM 332 Data sort by EPA ID\#

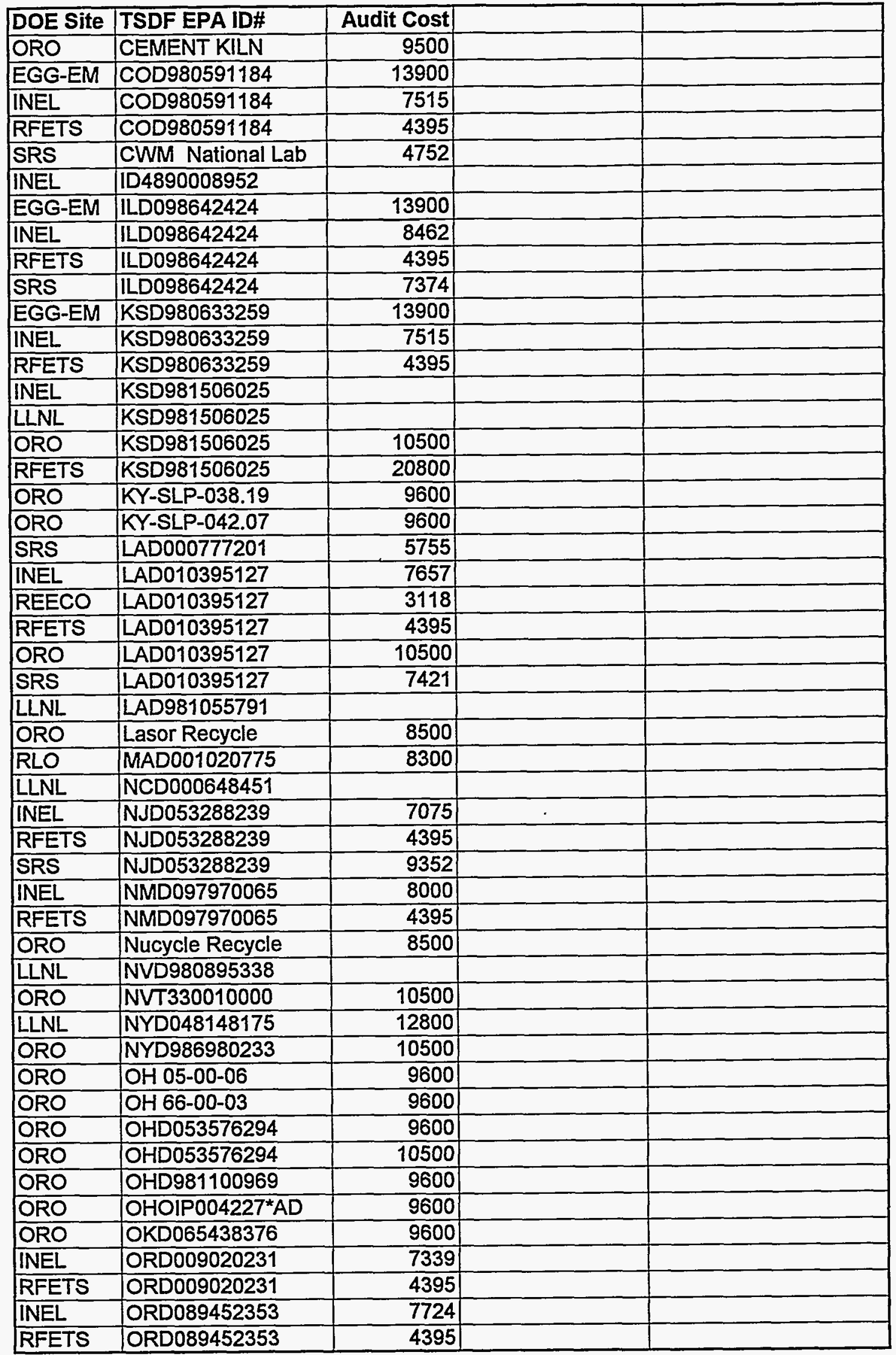


EM 332 Data sort by EPA ID\#

\begin{tabular}{|c|c|c|c|c|}
\hline DOE Site & TSDF EPA ID\# & Audit Cost & & \\
\hline EGG-EM & PAD002390961 & 13900 & & \\
\hline INEL & PAD002390961 & 7075 & & \\
\hline RFETS & PAD002390961 & 4395 & & \\
\hline EGG-EM & PAD087561015 & 13900 & & \\
\hline INEL & PAD087561015 & 7513 & & \\
\hline LLNL & PAD087561015 & 12800 & & \\
\hline RFETS & PAD087561015 & 4395 & & \\
\hline SRS & PAD087561015 & 5472 & & \\
\hline RLO & PAD980707087 & 9400 & & \\
\hline LLNL & PAD981939846 & & & \\
\hline ORO & RD\&D PERMIT & 10500 & & \\
\hline ORO & SALESCO & 10500 & & \\
\hline$\overline{\mathrm{LBL}}$ & SCD044442333 & 5600 & & \\
\hline SLAC & SCD044442333 & 4843 & & \\
\hline LLNL & TND000645770 & & & \\
\hline ORO & TND34692632 & 9500 & & \\
\hline ORO & TND932157570 & 15500 & & \\
\hline ORO & TND982109142 & 8500 & & \\
\hline SRS & TND982109142 & 6744 & & \\
\hline ORO & TNOSNL011030160 & 10500 & & \\
\hline SRS & TXD000838896 & 5755 & & \\
\hline EGG-EM & TXD055141378 & 13900 & & \\
\hline INEL & TXD055141378 & 7657 & & \\
\hline LLNL & TXD055141378 & 11600 & & \\
\hline REECO & TXD055141378 & 3042 & & \\
\hline ORO & TXD055141378 & 10500 & & \\
\hline SRS & TXD055141378 & 11933 & & \\
\hline RFETS & TXD055141387 & 4395 & & \\
\hline LLNL & TXD982560294 & & & \\
\hline LLNL & UTD981552177 & & & \\
\hline SLAC & UTD981552177 & 1083 & & \\
\hline INEL & UTD982589459 & & - & \\
\hline RFETS & UTD982589459 & 4395 & & \\
\hline SLAC & UTD982595795 & 1083 & & . \\
\hline INEL & UTD982598898 & 8208 & & \\
\hline LLNL & UTD991301748 & & & \\
\hline SLAC & UTD991301748 & 1083 & & \\
\hline $\mathrm{RLO}$ & UTD991301748 & 6500 & & \\
\hline $\mathrm{RLO}$ & WAD092300250 & 4300 & & \\
\hline RLO & WAD980978746 & 600 & & \\
\hline$\overline{\text { ORO }}$ & WVD988770673 & 9600 & & \\
\hline \multirow[t]{2}{*}{ ORO } & WVD988770673 & 9600 & & \\
\hline & AVERAGE COST $=$ & 7558 & & \\
\hline
\end{tabular}




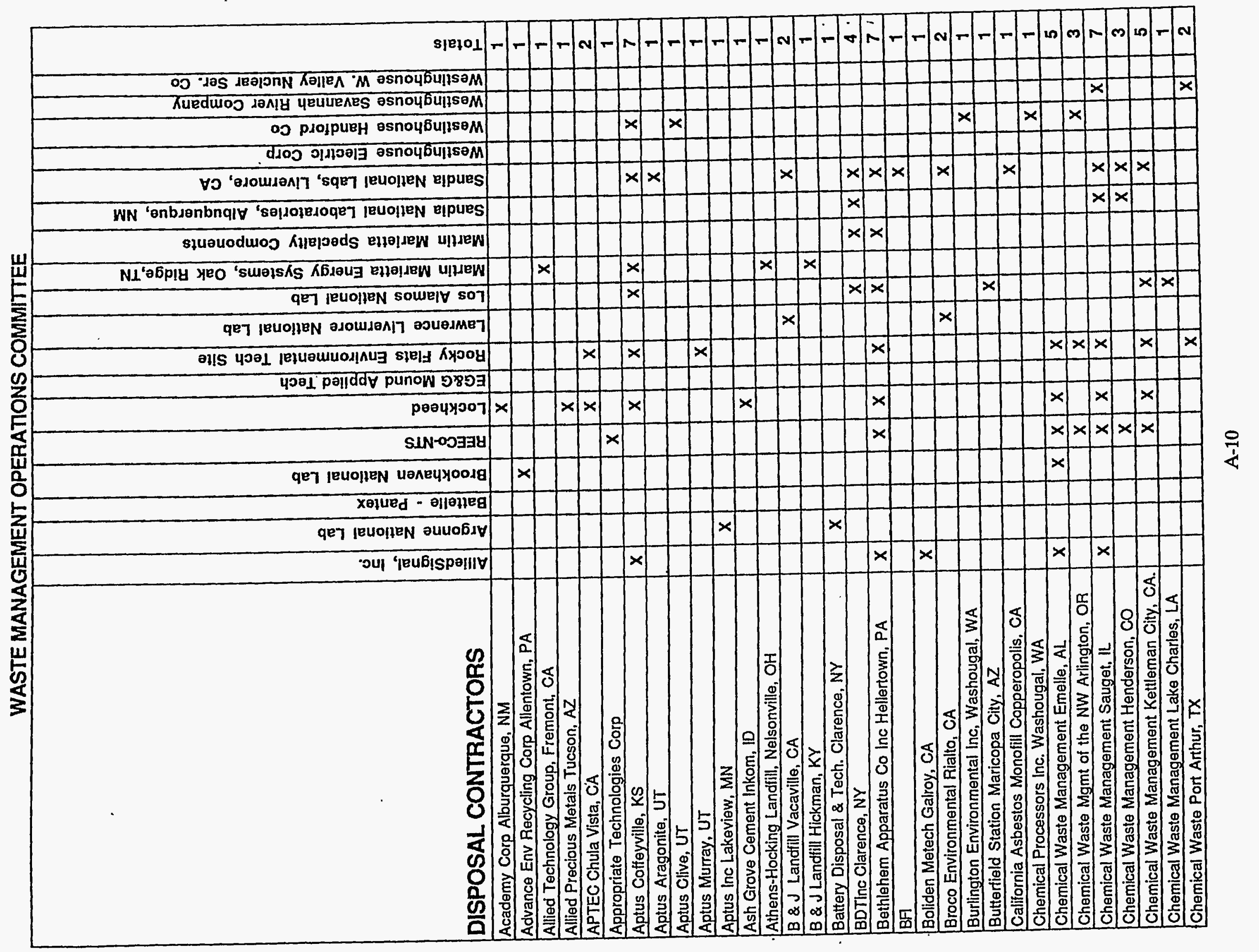


DISPOSAL CONTRACTORS

Chemwaste Modelcity, NY

Chemwaste Newark, NJ

Chestnut Ridge Landfill Heiskell. TN

Container Management Service Hayward, CA

Crosby and Overton, Kent, WA

Cowboy Oil Ocatello, ID
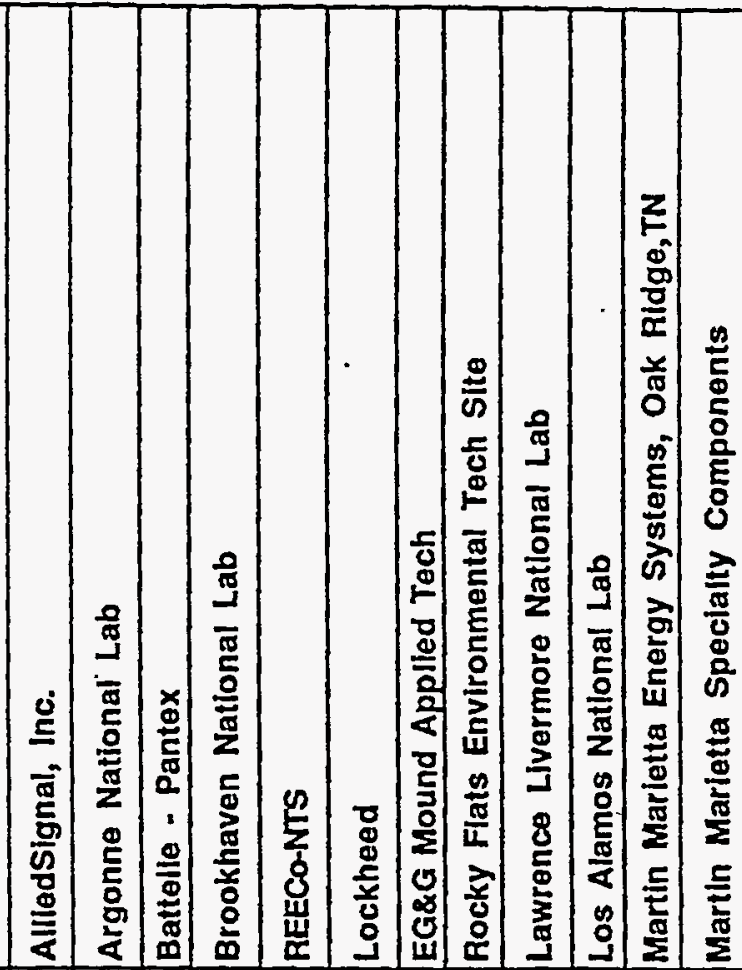

CWM Chemical Services Chicago, IL

Custom Environmental Transport, DE $\mathrm{X}$

Custom Environmental Transport Deer Park, TX

Cyanokam Detroit, MI

Dlxie Barrel, Knoxville, TN

$\mathrm{x}$

$+|\cdot| x \mid$

1

Diversified Scentitic Services Kingston, TN

Drew Resources Corp

DSSI Kingston, TX

\begin{tabular}{lll|l|l|}
\hline & & & & \\
\hline & & & & \\
\hline
\end{tabular}

$\mathrm{X}$

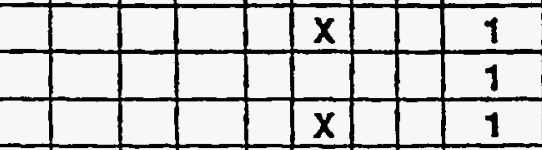

Eastern Smelting, Lynn, MA

Englehard Industries West Inc Anaheim, $C A$

ENSCO (AR) Little Rock, AR

ENSCO EL Dorado, AR

ENSCO West, INC. Wilmington, CA

$+1$

$\mathrm{X}$

$\mathbf{x}$

$\mathrm{x}$

ENSR, Canton, $\mathrm{OH}$

\begin{tabular}{llllll|l|l|l|l|l|l|}
\hline & & & & & & & & & & & $x$ \\
\hline
\end{tabular}

$\mathbf{x}$

1

ENCOTEC, Inc - Lab, Ann Arbor, MI

EPS, Wheeling, W. VA

Envirocare of Utah Clive, UT

\begin{tabular}{llllllll|l|l|}
\hline & & & & & & \\
\hline
\end{tabular}

X

$\mathrm{x} x$

$+$

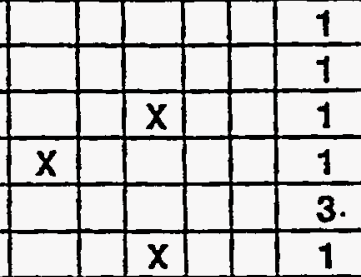

Environmental, Beaver Falls, PA

Enviromental Transportatin Ser OK City, OK

Essex Waste Management Kingville, MO

Eticam, Fernley, NV

$\mathrm{x}$

$\mathrm{x}$

$\mathrm{x}$

2

$\begin{array}{lll}x & x & x\end{array}$

$\mathrm{X}$

$\mathrm{x} x$

$\mathrm{x}$

$x$

1

Envirosafe Services Grandview, ID

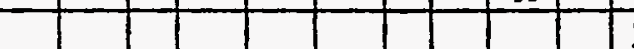

$\mathrm{x}$

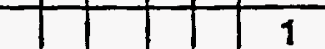

Envirosafe Boise, ID

Erickson, Richmond, CA

$x$

\begin{tabular}{l|l|}
\hline$x$ & 1 \\
\hline
\end{tabular}

\begin{tabular}{ll|l|l|l|l|l|l|l|l|l|}
\hline$x$ & \\
\hline
\end{tabular}

\begin{tabular}{|l|l|}
\hline $\mathrm{X}$ & \\
\hline $\mathrm{x}$ & \\
\hline
\end{tabular}

\begin{tabular}{|l|l|}
\hline$x$ & \\
\hline$x$ & \\
\hline
\end{tabular}

$\mathrm{x}$

1

Evergreen Environmental Services

Evergreen Oil Inc 


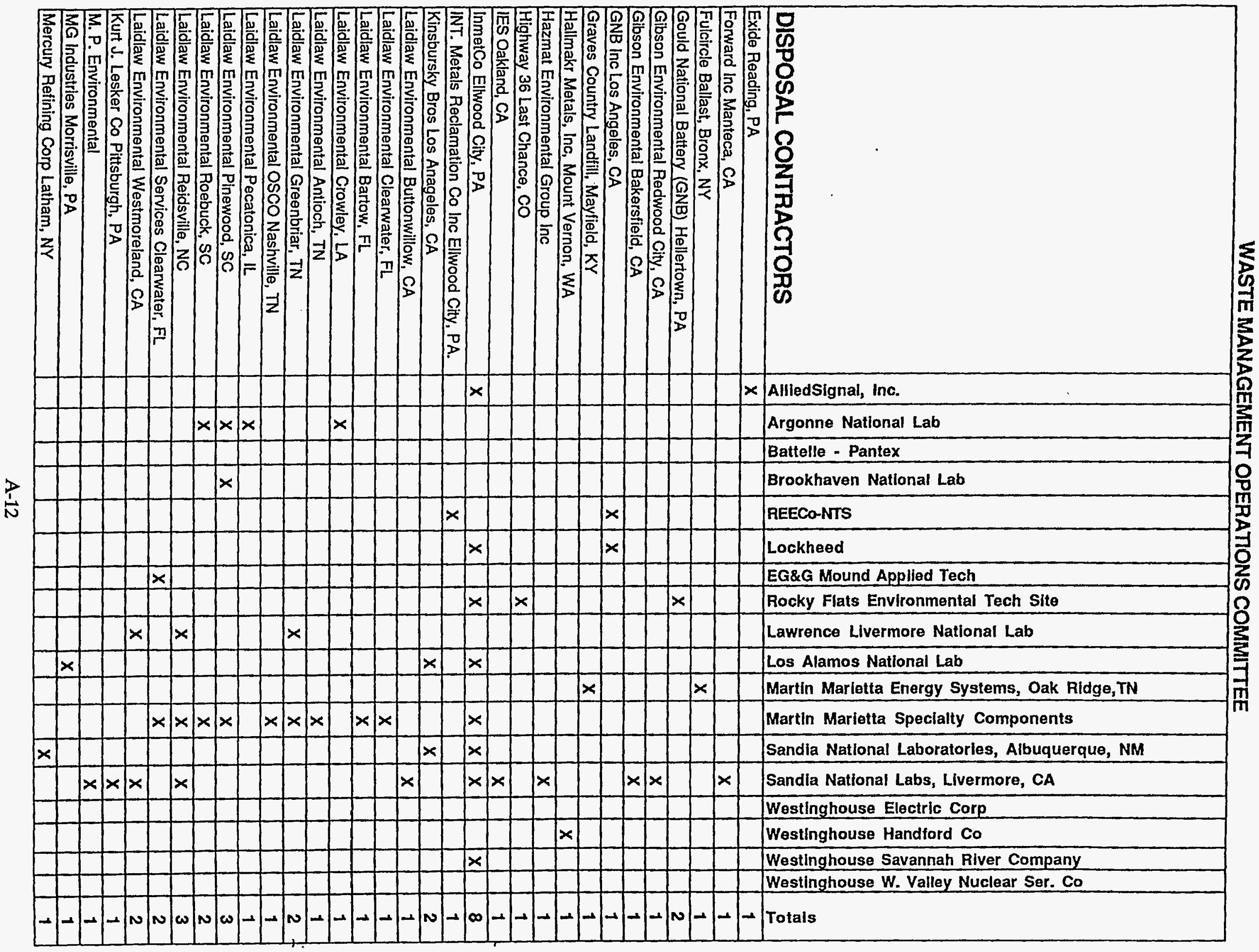




\section{DISPOSAL CONTRACTORS}

Mercury Technologies Hayward, CA

Norris Industries Inc

NSSI Recovery Services Houston, TX

Nucycle Technologies, Knaxvile, TN

$\mathrm{X}$
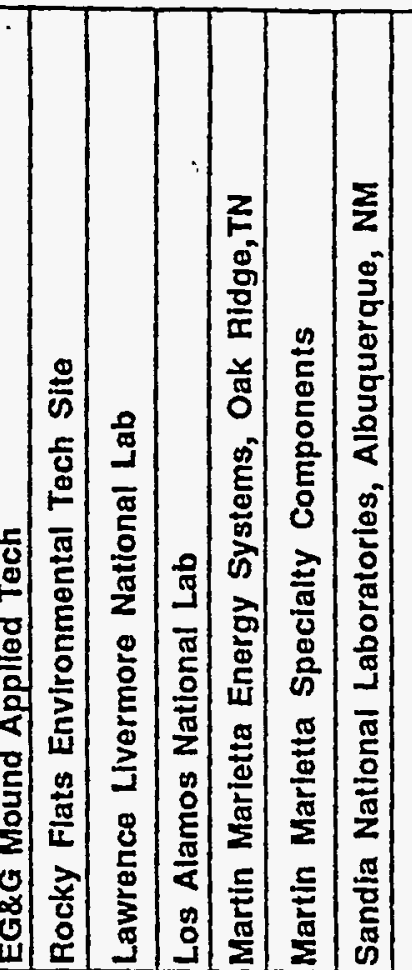

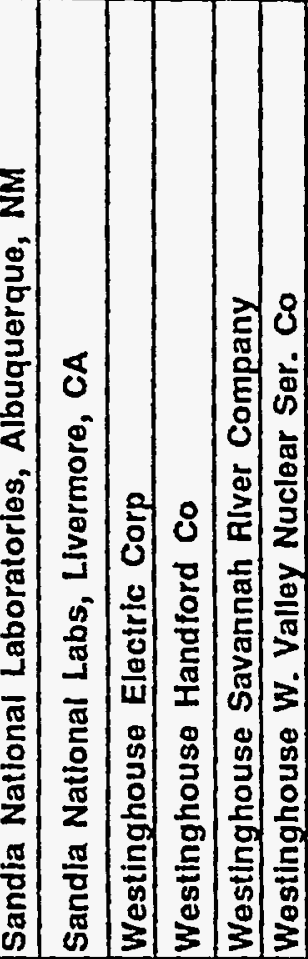

$\frac{\infty}{0}$

NW Enviroservice Inc Seattle, WA

Oil \& Solvent Process Co Henderson, CO

OSCO Treatment Systems Nashville, TN

Perma Fix

$x$

\begin{tabular}{ll|} 
& $x$ \\
\hline$x$ & $x$
\end{tabular}

1

Peoria Disposal Co Peoria, IL

$\mathrm{x}$

$\mathrm{x}$

$x$ x

$\frac{1}{3}$

Pike Sanitation Waverly, OH

Pinnaclo

Preferred Reduction Services

Quadrex

R\&D Fabricators Colfax, LA

Recyclights Minn, MN

$\mathrm{x}$

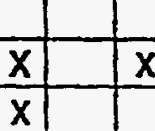

$\mathrm{x}$

$\mathrm{x}$

$\mathrm{X}$

1

Rollins Bethlehen, PA

Rollins - CET

Rollins Envir Services Baton Rouge, LA

Rollins Envir Services Bridgeport, NJ

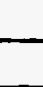

$\mathrm{x}$

\begin{tabular}{ll|l|l|}
\hline & & & \\
\hline & & & $x$ \\
\hline
\end{tabular}

$\mathrm{x}$

$\mathrm{x}$

$x$

$\mathrm{x}$

Rollins Envir Services Deer Park, TX

Rollins Envir Services Los Angeles, CA

Rollins OPC Los Angeles, CA

.

Romic Env Tech Corp East Palo Alto, CA

Romic Chemical Corp Chandler, AZ

Ross Incineration $(\mathrm{OH})$ Gratton, $\mathrm{OH}$

S. D. Meyers AZ

S. D. Moyers Tallmadge, $\mathrm{OH}$

Safety-Kleen Corp Pasco, WA

Safety-Kleen East Chicago, IN

\begin{tabular}{llllllll}
\hline & & & & & & & \\
\hline
\end{tabular}

\begin{tabular}{l|}
$\mathrm{x}$ \\
$\mathrm{x}$
\end{tabular}

$\mathrm{x}$

\begin{tabular}{ll|l|l|}
$x$ & & & 1 \\
\hline
\end{tabular}

Safety-Kleen Oakland, $C A$

$\mathrm{x}$

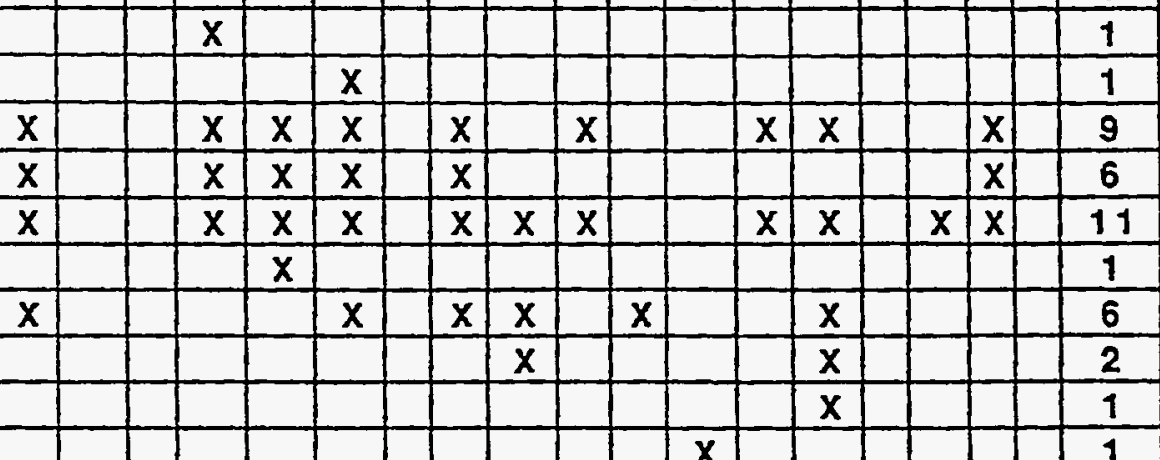

\begin{tabular}{|c|c|c|c|c|c|c|c|c|c|c|c|c|c|c|c|}
\hline & & $x$ & & & & & & & & & & & & & 1 \\
\hline & & & & $\mathbf{x}$ & & & & & & & & & & & 1 \\
\hline$x$ & & $x$ & $x$ & $x$ & & & & $\bar{x}$ & & & $x$ & $x$ & & $\mathbf{x}$ & 9 \\
\hline$x$ & & $x$ & $\mathrm{x}$ & $\mathrm{x}$ & & & & & & & & & & $\mathrm{x}$ & 6 \\
\hline$x$ & & $x$ & $x$ & $\mathrm{x}$ & & & $x$ & $x$ & & & $x$ & $x$ & $x$ & $\mathrm{x}$ & 11 \\
\hline & & & $x$ & & & & & & & & & & & & 1 \\
\hline$x$ & & & & $x$ & & & $x$ & & $x$ & & & $x$ & & & 6 \\
\hline & & & & & & & $x$ & & & & & $x$ & & & 2 \\
\hline & & & & & & & & & & & & $x$ & & & 1 \\
\hline & & & & & & & & & & & & & & & 1 \\
\hline
\end{tabular}

Safety-Kleen Corp Salida, CA

$\mathrm{x}$

$\mathrm{x}$

$\mathrm{x}$

$x$

$x$

2

Salesco Phoenix AZ

\begin{tabular}{llll|l|l|}
\hline & & & & & $x$ \\
\hline
\end{tabular}

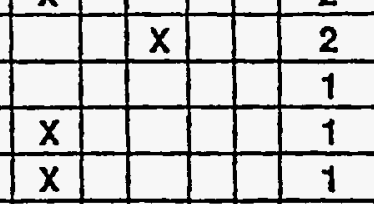

\begin{tabular}{l|l|l}
\hline$x$ & $x$ & $x$
\end{tabular} 


\section{DISPOSAL CONTRACTORS}
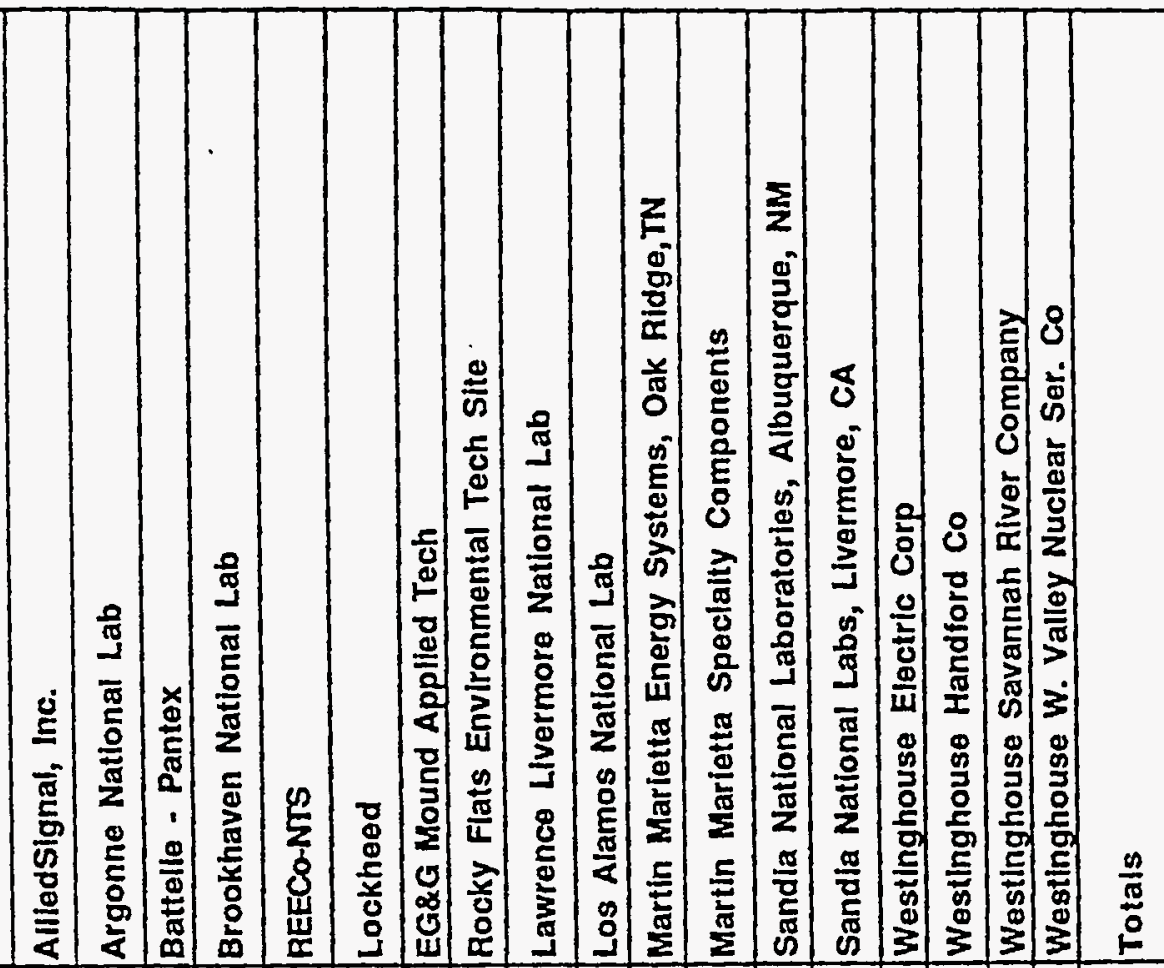

Sanders Lead Tory, AL

Sands Hill Coal Company Wellston, $\mathrm{OH}$

Scientific Ecology Group Kingston, TN

Signal Mountain Cement, Hixson, TN

Silver Recovery Associales, Longmont, CO

Systech/Lafarge Fredonia, KS

Solvent Services Inc San Jose, CA

Southeast Laser Knoxville, TN

Southern California Chem Co Garland, TX

Systech Envirnmental Co Fredonia, KS

Tektronics Beaverton, OR

Thermalkem Rock Hill, SC

Thomas Gray

Tri-Gas Albuquerque, NM

Trojan Batteries

US Ecology

United Refining Chicago, IL

USPCI Waynoka, OK

USPCI Wichita, KS

USPCI Grassy/Grayback Mtn Clive, UT

USPCI Hydrocarbon Recyclers Inc Tulsa, OK

USPCI Hydrocarbon Recyclers Inc Lone Mtn, OK

USPCI Solvent Services San Jose, CA

Waste Technologies Ind East Liverpool, $\mathrm{OH}$

WMI Medical Services Chandler, AZ

TOTALS

GRAND TOTALS

\begin{tabular}{|c|c|c|c|c|c|c|c|c|c|c|c|c|c|c|c|c|}
\hline$x$ & & & & & & & & & & $x$ & & & & & & 2 \\
\hline$x$ & & & & & & & & & & & & & & & & 1 \\
\hline$x$ & & & & & & & & $x$ & & & & $x$ & $x$ & $x$ & & 5 \\
\hline & & & & & & & & & & & & $x$ & & & & 1 \\
\hline & & & & & & & & & & & & $\mathrm{x}$ & & & & 1 \\
\hline & & & & & & & & $x$ & & & & & $x$ & & & 2 \\
\hline & $x$ & & & & & & & & & & & & & & & 1 \\
\hline & & & & & & $x$ & & & $\mathbf{x}$ & & & & & & & 2 \\
\hline & & & & & & & & & & & & & & & & 272 \\
\hline 24 & 10 & $x$ & 10 & 15 & 22 & 6 & 22 & 14 & 16 & 23 & 18 & 17 & 50 & \begin{tabular}{|l|l|}
$x$ & 16 \\
\end{tabular} & \begin{tabular}{|l|l|}
9 & $x$ \\
\end{tabular} & 272 \\
\hline
\end{tabular}




\section{Assumed Totals Per Most Current Updates}

Eighteen sites are represented in the Waste Management Operations Committee (WMOC) subcommittee. Fifteen sites have responded with information. These 15 sites use a total of 272 Treatment, Storage and Disposal (TSD) sites for disposal of various waste forms.

Upon review of information provided by the WMOC site representative, the following breakdown is as follows:

15 Contractors use 1 TSD $=$ 15 Contractors use 2 TSDs = 106

10 Contractors use 3 TSDs =

1 Contractor uses 4 TSDs $=$

3 Contractors use 5 TSDs =

3 Contractors use 6 TSDs =

3 Contractors use 7 TSDs =

1 Contractor uses 8 TSDs =

1 Contractor uses 9 TSDs =

1 Contractor uses 11 TSDs =

96 Audits budgeted and scheduled;

99 Audits that are scheduled but are not budgeted;

77 Audits still needing to be budgeted/scheduled.

272 Audits that can be performed. 


\begin{tabular}{|l|}
\hline \multicolumn{1}{|c|}{ DOE Site Name } \\
\hline Ames Laboratory - lowa State \\
\hline Argonne National Laboratory - East \\
\hline Battelle Pacific Northwest Labs \\
\hline Bettis Atomic Power Lab \\
\hline Brookhaven National Laboratory \\
\hline Colonie Interim Storage Site \\
\hline EG\&G - Los Alamos \\
\hline EG\&G Energy Measurements \\
\hline EG\&G Rocky Flats \\
\hline Fermi Lab \\
\hline Fernald Environmental Management \\
\hline Hanford \\
\hline Idaho National Engineering Laboratory \\
\hline K-25 Site \\
\hline Kansas City Plant \\
\hline Knolls Atomic Power Lab - Kesselring Site \\
\hline Knolls Atomic Power Lab - Schenectady \\
\hline Knolls Atomic Power Lab - Windsor Site \\
\hline Lawrence Berkeley Laboratory \\
\hline Lawrence Livermore National Laboratory \\
\hline Los Alamos National Laboratory \\
\hline Lovelace ITRI \\
\hline Mound Plant \\
\hline Oak Ridge National Laboratory, X-10 \\
\hline Paducah Gaseous Diffusion Plant \\
\hline Pantex Plant \\
\hline Pinellas Plant \\
\hline Portsmouth Gaseous Diffusion Plant \\
\hline Princeton Plasma Physics Lab \\
\hline Reynolds Electrical and Engineering Company, Inc. \\
\hline Sandia National Laboratories - Alb \\
\hline Sandia National Laboratories - Livermore \\
\hline Savannah River \\
\hline Stanford Linear Accelerator Center \\
\hline Tonopah Test Range \\
\hline U.S. Department of Energy \\
\hline Waste Isolation Pilot Plant - Carlsbad \\
\hline West Valley Demonstration Project \\
\hline Y-12 \\
\hline
\end{tabular}


(as contained in the SMAC system)*

\begin{tabular}{|c|c|}
\hline TSDF EPA ID\# & TSDF NAME \\
\hline ALD000622464 & Chemical Waste Management, Inc., Emelle Facility \\
\hline ARD069748192 & Environmental Systems Company (ENSCO), Inc. \\
\hline AZD009015389 & Romic Chemical Corporation, Southwest \\
\hline AZD049318009 & Recycling Resources, Inc. \\
\hline AZD982441263 & Westate Catbon - Arizona Inc. \\
\hline AZD982465866 & S.D. Myers \\
\hline AZT050010180 & Chemical Waste Management, Inc. \\
\hline CA2890012584 & Lawrence Livermore National Laboratory \\
\hline CA2890090002 & Lawrence Livermore National Laboratory \\
\hline CAD000628149 & Haz/Control \\
\hline CAD000633164 & Laidlaw Environmental Services \\
\hline CAD004771168 & H\& H Ship Service Company \\
\hline CAD008302903 & Oil and Solvent Process Company \\
\hline CAD009452657 & Romic Chemical \\
\hline CAD009466392 & Erickson, Inc. \\
\hline CAD050806850 & Rollins OPC \\
\hline CAD053044053 & Safety-Kleen Corporation \\
\hline CAD059494310 & USPCI Treatment \& Recovery Services \\
\hline CAD070148432 & Drew Resources Corp. \\
\hline CAD074644659 & Baron-Blakeslee \\
\hline CAD083166728 & Refineries Services \\
\hline CAD087210399 & Western Drums, Inc. \\
\hline CAD088504881 & Kinsbursky Brothers \\
\hline CAD097030993 & Norris Industries, Inc. \\
\hline CAD980887418 & Evergreen Oil, Inc. \\
\hline CAD981424732 & Quicksilver Products, Inc. \\
\hline CAD982042475 & B \& J Sanitary Landfill \\
\hline CAD982518623 & GC Industries \\
\hline CALO00027741 & California Asbestos Monofill \\
\hline CALO00048571 & Alviso Indepentent Oil \\
\hline CAT000613950 & Safety-Kleen Corporation \\
\hline CAT000613968 & Safety-Kleen Corporation \\
\hline CAT000646117 & Chemical Waste Management, Inc. \\
\hline CAT080014079 & California AETC \\
\hline CAT080022148 & Broco, Inc. \\
\hline CAT080031628 & National Cement Co./SYSTECH \\
\hline CAT080033681 & Chem Tech Systems \\
\hline CAT087210399 & Western Drums, Inc. \\
\hline COD980591184 & Chemical Waste Management \\
\hline COD991300484 & Highway 36 Land Development Co. \\
\hline CTD072138969 & Environmental Waste Resources \\
\hline FLD000776708 & Chemical Waste Management, Inc. Pompano Beach Fac. \\
\hline FLD980711071 & Quadrex Environmental Co. \\
\hline FLD980729610 & Laidlaw Environmental Services of Bartow, Inc. \\
\hline FLD981474802 & Laidlaw Environmental Services (TS) Inc. \\
\hline IAT200010601 & Iowa State University \\
\hline ID0073114654 & Envirosafe of Idaho \\
\hline ID4890008952 & INEL clo EG\&G Idaho \\
\hline IDD991281270 & Safety-Kleen Corporation \\
\hline ILD000646786 & Motor Oils Refining \\
\hline ILD000665851 & Safety-Kleen Corporation \\
\hline ILD000805911 & Safety-Kleen Corporation \\
\hline ILD085349264 & Heritage Environmental Services, Inc.- Lemont Fac. \\
\hline ILD098642424 & Trade Waste Incineration \\
\hline ILD980502744 & Laidlaw Env. Services of Illinois, Inc. \\
\hline ILD984774695 & Mar-Cor Industries, Inc. \\
\hline IND077042034 & Saftey-Kleen Oil Recovery Breslube \\
\hline KSD007246846 & Hydrocarbon Recyclers, Inc. \\
\hline KSD981506025 & Aptus, Ine. \\
\hline KYD053348108 & Safety-Kleen Corporation \\
\hline LAD000777201 & Chemical Waste Management, Inc. \\
\hline LAD010395127 & Rollins Environmental Services (LA), Inc. \\
\hline LAD981055791 & Laidlaw Environmental Services Inc. \\
\hline MAD001020775 & Eastern Smelting \& Refining Corp. \\
\hline MAD053452637 & Clean Harbors of Braintree, Inc. \\
\hline
\end{tabular}


COMMERCIAL TSDFS USED BY DOE SITES IN CY 1992

(as contained in the SMAC system)*

\begin{tabular}{|c|c|}
\hline MAD980523203 & Clean Harbors of Natick, Inc. \\
\hline MDD980534653 & Clean Harbors of Baltimore, Inc. \\
\hline MND980996805 & Enviro-Chem, Inc. \\
\hline MND981190242 & Aptus \\
\hline MOD981506611 & Tipton Environmental Technology, Inc. \\
\hline N/A & Settlers Hil! Landfill \\
\hline NCD000648451 & Laidlaw Environmental Services (TC), Inc. \\
\hline NJD045995693 & Casie Ecology Oil Salvage \\
\hline NJD053288239 & Rollins Environmental Services (NJ), Inc. \\
\hline NJD089216790 & Chemical Waste Management of New Jersey \\
\hline NJD980536593 & Advanced Environmental Technology Corporation \\
\hline NMD000804294 & Saftey-Kleen Corporation \\
\hline NMD097138382 & Southwest Radiographics, Inc. \\
\hline NMD097970065 & Academy Corp. \\
\hline NONE & Rockford/Interstate Pollution Control, Inc \\
\hline NONE2 & Browning Ferris Industries \\
\hline NONE3 & Waste Management, Inc., Medical Services of AZ \\
\hline NV3890090001 & Reynolds Electrical and Engineering \\
\hline NVD980895338 & ETICAM \\
\hline NVT330010208 & Safety-Kleen Corporation \\
\hline NVY330010000 & U.S. Ecology \\
\hline NYD000632372 & BDT, Inc. \\
\hline NYD048148175 & Mercury Refining Company \\
\hline NYD049836679 & CWM Chemical Services Inc. \\
\hline OHD000724153 & Clean Harbors of Cleveland, Ohio \\
\hline OHD045242706 & Envirosafe Services of Ohio \\
\hline OHD053576294 & S.D. Myers \\
\hline OHD980683155 & Safety-Kleen Corporation \\
\hline OHD981093420 & Unison Transformer Services, Inc. \\
\hline OHD981893420 & Unison Transformer Services, Inc. \\
\hline OKD000632737 & Hydrocarbon Recyclers, Inc. \\
\hline OKD065438376 & USPCI - Lone Mountain Facility \\
\hline OKD981514284 & East Oaks Landfill \\
\hline ORD980980775 & Industrial Oil Co. \\
\hline PA0002390961 & Bethlehem Apparatus Company, Inc. \\
\hline PAD085690592 & Republic Environment Systems, (PA), Inc. \\
\hline PAD087561015 & INMETCO \\
\hline PAD981113749 & PPM, Inc. \\
\hline PAD990753089 & General Barrery Corporation \\
\hline SCD070375985 & GSX Services of South Carolina \\
\hline SCD077995488 & Safety-Kleen Corporation \\
\hline TN0890090004 & K-25 Site \\
\hline TN1890090003 & Oak Ridge National Laboratory, $\mathrm{X}-10$ \\
\hline TND000645770 & Laidlaw Environmental Services (TS) Inc. \\
\hline TND000772186 & CWM - Memphis Service Facility \\
\hline TND096070396 & Ross Metals, Inc. \\
\hline TND982109142 & Diversified Scientific Services, Inc. \\
\hline TXD000747410 & Safety-Kleen Corporation \\
\hline TXD000747428 & Safety-Kleen Corporation \\
\hline TXD000838896 & Chemical Waste Management, Inc. \\
\hline TXD047823265 & Southern California Chemical Company \\
\hline TXD055141378 & Rollins Environmental Services (TX), Inc. \\
\hline TXD981056690 & Safety-Kleen Corporation \\
\hline TXD982560294 & NSSI/Recovery Services, Inc. \\
\hline UTD981552177 & Aptus Environmental Services \\
\hline UTD982598898 & Envirocare of Utah, inc. \\
\hline UTD 991301748 & USPCI - Grassy Mountain Facility \\
\hline VAD988186623 & Chemical Waste Management, Inc. \\
\hline WA7890008967 & Westinghouse Hanford Co. \\
\hline WAD092300250 & Burlington Environmental, Inc. \\
\hline WAD980978746 & Safety-Kleen Corporation \\
\hline WAS087462503 & Fuels Processors, inc. \\
\hline WID000808824 & Avganic Industries, Inc. \\
\hline
\end{tabular}


COMMERCIAL TSDFS USED BY DOE SITES IN CY 1993

(as contained in the SMAC system)*

\begin{tabular}{|c|c|}
\hline TSDF EPA ID\# & TSDF NAME \\
\hline 06306000001 & Community Landfill Company \\
\hline ALD000622464 & Chemical Waste Management, Inc., Emelle Facility \\
\hline ARD069748192 & Environmental Systems Company (ENSCO), Inc. \\
\hline AZD049318009 & Recycling Resources, Inc. \\
\hline AZD982441263 & Westate Catbon - Arizona Inc. \\
\hline AZD982465866 & S.D. Myers \\
\hline AZT050010180 & Chemical Waste Management, Inc. \\
\hline CA2890012584 & Lawrence Livermore National Laboratory \\
\hline CAD000628149 & Haz/Control \\
\hline CAD000633164 & Laidlaw Environmental Services \\
\hline CAD004771168 & H \& H Ship Service Company \\
\hline CAD008302903 & Oil and Solvent Process Company \\
\hline CAD008488025 & Southern California Chemical \\
\hline CAD009203100 & PRC Patterson, Inc. \\
\hline CAD009452657 & Romic Chemical \\
\hline CAD009466392 & Erickson, Inc. \\
\hline CAD043260702 & Gibson Environmental \\
\hline CAD050806850 & Rollins OPC \\
\hline CAD053044053 & Safety-Kleen Corporation \\
\hline CAD059494310 & USPCI Treatment \& Recovery Services \\
\hline CAD070148432 & Drew Resources Corp. \\
\hline$\overline{C A D 087210399}$ & Western Drums, Inc. \\
\hline CAD097030993 & Norris Industries, Inc. \\
\hline CAD980675276 & Laidlaw Environmental Services \\
\hline CAD980883177 & Gibson Environmental \\
\hline CAD980884183 & Chemical Waste Management, Inc. \\
\hline CAD980887418 & Evergreen Oil, Inc. \\
\hline CAD980888598 & W.I.T. Sales and Refining \\
\hline CAD982042475 & B \& J Sanitary Landfill \\
\hline CAD982446890 & Evergreen Environmental Services \\
\hline CAD990794133 & Fonward, Inc. \\
\hline CALO00027741 & California Asbestos Monofill \\
\hline CAL000048571 & Alviso Indepentent Oil \\
\hline CAT000612150 & Englehard Industries West, Inc. \\
\hline CAT000613968 & Safety-Kleen Corporation \\
\hline CAT000646117 & Chemical Waste Management, Inc. \\
\hline CAT080014079 & California AETC \\
\hline CAT080022148 & Broco, Inc. \\
\hline CAT080031628 & National Cement Co.I SYSTECH \\
\hline CAT087210399 & Western Drums, Inc. \\
\hline COD980591184 & Chemical Waste Management \\
\hline COD991300484 & Highway 36 Land Development Co. \\
\hline CTD000604488 & Clean Harbors of Connecticut, Inc. \\
\hline CTD072138969 & Environmental Waste Resources \\
\hline FLD980711071 & Quadrex Environmental Co. \\
\hline FLD981474802 & Laidlaw Environmental Services (TS) Inc. \\
\hline ID0073114654 & Envirosafe of Idaho \\
\hline ID4890008952 & INEL c/o EG\&G Idaho \\
\hline ILD000608471 & Clean Harbors of Chicago, Inc. \\
\hline ILD000805911 & Safety-Kleen Corporation \\
\hline ILD051937068 & Allied Signal, Inc. \\
\hline ILD085349264 & Heritage Environmental Services, Inc.- Lemont Fac. \\
\hline ILD098642424 & Trade Waste Incineration \\
\hline ILD980502744 & Laidlaw Env. Services of Illinois, Inc. \\
\hline ILD980613913 & Safety-Kleen Corporation \\
\hline ILD984774695 & Mar-Cor Industries, Inc. \\
\hline IN0984899740 & Solar Environmental, Inc. \\
\hline IND077042034 & Saftey-Kleen Oil Recovery Breslube \\
\hline KSD007246846 & Hydrocarbon Recyclers, Inc. \\
\hline KSD981506025 & Aptus, Inc. \\
\hline KSD981506321 & Aptus, Inc. \\
\hline KYD005009923 & Calgon Carbon Corporation \\
\hline LAD000777201 & Chemical Waste Management, Inc. \\
\hline LAD010395127 & Rollins Environmental Services (LA), Inc. \\
\hline LAD981055791 & Laidlaw Environmental Services Inc. \\
\hline
\end{tabular}


COMMERCIAL TSDFS USED BY DOE SITES IN CY 1993

(as contained in the SMAC system)*

\begin{tabular}{|c|c|}
\hline MAD001020775 & Eastern Smelting \& Refining Corp. \\
\hline MAD053452637 & Clean Harbors of Braintree, Inc. \\
\hline MAD980523203 & Clean Harbors of Natick, lnc. \\
\hline MAD991302266 & Merrimack Valley Medical Services \\
\hline MID000724831 & Envotech Management Services \\
\hline MID048090633 & Wayne Disposal \\
\hline MID096963194 & Chem Met Services, Inc. \\
\hline MID098011992 & CyanoKem \\
\hline MND981190242 & Aptus \\
\hline MOD981506611 & Tipton Environmental Technology, Inc. \\
\hline NCD000648451 & Laidlaw Environmental Services (TC), Inc. \\
\hline NJD045995693 & Casie Ecology Oil Salvage \\
\hline NJD053288239 & Rollins Environmental Services (NJ), Inc. \\
\hline NJD089216790 & Chemical Waste Management of New Jersey \\
\hline NJD980536593 & Advanced Environmental Technology Corporation \\
\hline NMD000804294 & Saftey-Kleen Corporation \\
\hline NMD097138382 & Southwest Radiographics, Inc. \\
\hline NMD097970065 & Academy Corp. \\
\hline NONE2 & Browning Ferris Industries \\
\hline NONE3 & Waste Management, Inc., Medical Services of $A Z$ \\
\hline NONE4 & Town \& Country Waste Servic / BFI \\
\hline NONE5 & Winnebago Reclamation Service \\
\hline NV3890090001 & Reynolds Electrical and Engineering \\
\hline NVD980895338 & ETICAM \\
\hline NYD000632372 & BDT, Inc. \\
\hline NYD000708198 & Safety-Kleen Corporation \\
\hline NYD048148175 & Mercury Refining Company \\
\hline NYD049836679 & CWM Chemical Services Inc. \\
\hline NYD084069426 & CIERO Petroleum Products, Inc. \\
\hline OHD000724153 & Clean Harbors of Cleveland, Ohio \\
\hline OHD045242706 & Envirosafe Services of Ohio \\
\hline OHD053576294 & S.D. Myers \\
\hline OHD093945293 & Chemical Waste Management, Inc. \\
\hline OHD980683155 & Safety-Kleen Corporation \\
\hline OHD981093420 & Unison Transformer Services, Inc. \\
\hline OKD000632737 & Hydrocarbon Recyclers, Inc. \\
\hline OKD065438376 & USPCI - Lone Mountain Facility \\
\hline PA0002390961 & Bethlehem Apparatus Company, Inc. \\
\hline PAD085690592 & Republic Environment Systems, (PA), Inc. \\
\hline PAD087561015 & INMETCO \\
\hline RID040098352 & Northland Environmental. Inc. \\
\hline SCD044442333 & ThermalKEM Inc. \\
\hline SCD077995488 & Safety-Kleen Corporation \\
\hline TN0890090004 & K-25 Site \\
\hline TN1890090003 & Oak Ridge National Laboratory, X-10 \\
\hline TN3890090001 & Y-12 Plant \\
\hline TND000645770 & Laidlaw Environmental Services (TS) Inc. \\
\hline TXD000747410 & Safety-Kleen Corporation \\
\hline TXD000747428 & Safety-Kleen Corporation \\
\hline TXD000838896 & Chemical Waste Management, Inc. \\
\hline TXD008117186 & Encycle/Texas, Inc. \\
\hline TXD047823265 & Southem California Chemical Company \\
\hline TXD055135388 & Treatment GNE \\
\hline TXD055141348 & Rollins Environmental Services (TX), Inc. \\
\hline TXD055141378 & Rollins Environmental Services (TX), Inc. \\
\hline TXD981056690 & Safety-Kleen Corporation \\
\hline TXD982560294 & NSSI/Recovery Services, Inc. \\
\hline TXD988077640 & Recovery \& Reclamation, Inc. \\
\hline UTD980957088 & Safety-Kleen Corporation \\
\hline UTD981552177 & Aptus Environmental Services \\
\hline UTD982598898 & Envirocare of Utah, Inc. \\
\hline UTD991301748 & USPCI - Grassy Mountain Facility \\
\hline WA7890008967 & Westinghouse Hanford Co. \\
\hline WAD000812909 & Burlington Environmental, Inc. \\
\hline WAD092300250 & Burlington Environmental, Inc. \\
\hline WAD980978746 & Safety-Kleen Corporation \\
\hline
\end{tabular}


(as contained in the SMAC system)*

\begin{tabular}{|c|c|}
\hline TSDF EPA ID\# & TSDF NAME \\
\hline 1978170006 & CDT LANDFILL CORP. - EXPANSION SITE \\
\hline ALD000622464 & Chemical Waste Management, Inc., Emelle Facility \\
\hline ALD983167891 & Trans-Cycle Industries, Inc. \\
\hline ARD069748192 & Environmental Systems Company (ENSCO), Inc. \\
\hline AZD009015389 & Romic Chemical Corporation, Southwest \\
\hline AZD982465866 & S.D. Myers \\
\hline AZD983473539 & Salesco Systems USA, Inc. \\
\hline AZT050010180 & Chemical Waste Management, Inc. \\
\hline CA4890008986 & Lawrence Berkeley Lab \\
\hline$\overline{C A D 000633164}$ & Laidlaw Environmental Services \\
\hline CAD008302903 & Oil and Solvent Process Company \\
\hline CAD009452657 & Romic Chemical \\
\hline CAD009466392 & Erickson, Inc. \\
\hline CAD043260702 & Gibson Environmental \\
\hline CAD050806850 & Rollins OPC \\
\hline CAD053044053 & Safety-Kleen Corporation \\
\hline CAD059493310 & UNITED STATES POLLUTION CONTROL/TRS \\
\hline CAD059494310 & USPCI Treatment \& Recovery Services \\
\hline CAD070148432 & Drew Resources Corp. \\
\hline CAD077182293 & Boliden Metech, Inc. \\
\hline CAD087210399 & Western Drums, Inc. \\
\hline CAD088504881 & Kinsbursky Brothers \\
\hline CAD097030993 & Norris Industries, Inc. \\
\hline CAD980675276 & Laidlaw Environmental Services \\
\hline$\overline{\text { CAD980887418 }}$ & Evergreen Oil, Inc. \\
\hline CAD982042475 & B \& J Sanitary Landfill \\
\hline CAD982446890 & Evergreen Environmental Services \\
\hline CAL000027741 & California Asbestos Monofill \\
\hline CALO00048571 & Alviso Indepentent Oil \\
\hline CAT000612150 & Englehard Industries West, Inc. \\
\hline CAT000613968 & Safety-Kleen Corporation \\
\hline CAT000646117 & Chemical Waste Management, Inc. \\
\hline CAT080014079 & California AETC \\
\hline CAT080022148 & Broco, Inc. \\
\hline CAT087210399 & Western Drums, Inc. \\
\hline C09048742175 & Hazen Research Inc \\
\hline COD980591184 & Chemical Waste Management \\
\hline CTD021816889 & United Oil Recovery \\
\hline FLD980711071 & Quadrex Environmental Co. \\
\hline FLD980729610 & Laidlaw Environmental Services of Bartow, Inc. \\
\hline $1 D 0073114654$ & Envirosafe of ldaho \\
\hline 104890008952 & INEL c/o EG\&G Idaho \\
\hline IDD073114654 & Envirosafe Services of ldaho, Inc. \\
\hline ILD000608471 & Clean Harbors of Chicago, Inc. \\
\hline ILD000805911 & Safety-Kleen Corporation \\
\hline ILD098642424 & Trade Waste Incineration \\
\hline ILD980502744 & Laidlaw Env. Services of llitinois, Inc. \\
\hline ILD980613913 & Safety-Kleen Corporation \\
\hline ILD984774695 & Mar-Cor Industries, Inc. \\
\hline IND000717959 & General Battery/Exide Corp. \\
\hline IND005081542 & ESSROC/CPR Inc. \\
\hline IND093219012 & Heritage Environmental Services \\
\hline KSD981506025 & Aptus, Inc. \\
\hline KYD053348108 & Safety-Kleen Corporation \\
\hline LAD010395127 & Rollins Environmental Services (LA), Inc. \\
\hline LAD981055791 & Laidlaw Environmental Services Inc. \\
\hline MAD053452637 & Clean Harbors of Braintree, Inc. \\
\hline MAD066588005 & Murphys Waste Oil Service \\
\hline MAD980523203 & Clean Harbors of Natick, Inc. \\
\hline MID096963194 & Chem Met Services, Inc. \\
\hline MND006153423 & Light Cycle, Inc. \\
\hline MND981190242 & Aptus \\
\hline MOD981506611 & Tipton Environmental Technology, Inc. \\
\hline N/A & Settlers Hill Landfill \\
\hline
\end{tabular}


COMMERCIAL TSDFS USED BY DOE SITES IN CY 1994

(as contained in the SMAC system)*

\begin{tabular}{|c|c|}
\hline NJD045995693 & Casie Ecology Oil Salvage \\
\hline NJD053288239 & Rollins Environmental Services (NJ), Inc. \\
\hline NJD089216790 & Chemical Waste Management of New Jersey \\
\hline NJD980536593 & Advanced Environmental Technology Corporation \\
\hline NM0890010515 & Los Alamos National Laboratory \\
\hline NM9570024423 & Kirtland Air Force Base \\
\hline NMD000804294 & Saftey-Kleen Corporation \\
\hline NONE & Rockford/Interstate Pollution Control, Inc \\
\hline NONE2 & Browning Ferris Industries \\
\hline NONE6 & Mallard Lake Landfill (BFl) \\
\hline NVD980895338 & ETICAM \\
\hline NYD000632372 & BDT, Inc. \\
\hline NYD049178296 & Radiac Research Corporation \\
\hline NYD049836679 & CWM Chemical Services Inc. \\
\hline NYD077444263 & Chemical Waste Disposal Corporation \\
\hline NYD986980233 & FULCIRCLE BALLAST RECYCLERS \\
\hline OHD053576294 & S.D. Myers \\
\hline OHD093945293 & Chemical Waste Management, Inc. \\
\hline OHD980683155 & Safety-Kleen Corporation \\
\hline OHD981093420 & Unison Transformer Services, Inc. \\
\hline OKD000632737 & Hydrocarbon Recyclers, Inc. \\
\hline OKD065438376 & USPCI - Lone Mountain Facility \\
\hline OR0089452353 & CHEMICAL WASTE MANAGEMENT \\
\hline PA0002390961 & Bethlehem Apparatus Company, Inc. \\
\hline PAD064375470 & Chemical Waste Management of Pennsylvannia, Inc. \\
\hline PAD085690592 & Republic Environment Systems, (PA), Inc. \\
\hline PAD087561015 & INMETCO \\
\hline PAD980707087 & Envirotrol, Inc. \\
\hline PAD981939846 & Kurt J. Lesker Company \\
\hline PAD987367216 & Advanced Environmental Recycling Corporation \\
\hline SCD070375985 & GSX Services of South Carolina \\
\hline SCD077995488 & Safety-Kleen Corporation \\
\hline SCD987588084 & Clemson Technical Center \\
\hline TN0890090004 & K-25 Site \\
\hline TN1890090003 & Oak Ridge National Laboratory, X-10 \\
\hline TNN3890090001 & Y-12 Plant \\
\hline TND000645770 & Laidlaw Environmental Services (TS) Inc. \\
\hline TND000770479 & IT Technology Development Laboratory \\
\hline TND003095635 & Nuclear Fuel Services, Inc. \\
\hline TND981933120 & IT Environmental Technology Development Laboratory \\
\hline TND982109142 & Diversified Scientific Services, Inc. \\
\hline TXD000747428 & Safety-Kleen Corporation \\
\hline TXD000838896 & Chemical Waste Management, Inc. \\
\hline TXD055141348 & Rollins Environmental Services (TX), lnc. \\
\hline TXD055141378 & Rollins Environmental Services (TX), Inc. \\
\hline TXD077603371 & Saftey Kleen Corporation \\
\hline TXD981056690 & Safety-Kleen Corporation \\
\hline TXD982290140 & Laidlaw Environmental Services, Inc. (TES) \\
\hline TXD982560294 & NSSI/Recovery Services, Inc. \\
\hline UTD980957088 & Safety-Kleen Corporation \\
\hline UTD981552177 & Aptus Environmental Services \\
\hline UTD982598898 & Envirocare of Utah, Inc. \\
\hline UTD991301748 & USPCI - Grassy Mountain Facility \\
\hline \multicolumn{2}{|l|}{ WA789000896 } \\
\hline WA7890008967 & Westinghouse Hanford Co. \\
\hline WAD009477175 & Cameron Yakima, Inc. \\
\hline WAD058367152 & Northwest Enviroservice Inc. \\
\hline WAD092300250 & Burlington Environmental, Inc. \\
\hline WAD980978746 & Safety-Kleen Corporation \\
\hline WID000808824 & Avganic Industries, Inc. \\
\hline
\end{tabular}




\begin{tabular}{|c|c|}
\hline SITE NAME & $\begin{array}{l}\text { Number of Unique } \\
\text { TSDFs Used }\end{array}$ \\
\hline Ames Laboratory - lowa State & 2 \\
\hline Argonne National Laboratory - East & 7 \\
\hline Bettis Atomic Power Lab & 5 \\
\hline Brookhaven National Laboratory & 7 \\
\hline Colonie Interim Storage Site & 1 \\
\hline EG\&G - Los Alamos & 2 \\
\hline EG\&G Energy Measurements & 8 \\
\hline EG\&G Rocky Flats & 5 \\
\hline Fermi Lab & 12 \\
\hline Fernald Environmental Management & 1 \\
\hline Hanford & 6 \\
\hline Idaho National Engineering Laboratory & 10 \\
\hline K-25 Site & 1 \\
\hline Kansas City Plant & 9 \\
\hline Knolls Atomic Power Lab - Kesselring Site & 5 \\
\hline Knolls Atomic Power Lab - Schenectady & 5 \\
\hline Knolls Atomic Power Lab - Windsor Site & 3 \\
\hline Lawrence Berkeley Laboratory & 7 \\
\hline Lawrence Livermore National Laboratory & 28 \\
\hline Los Alamos National Laboratory & 11 \\
\hline Lovelace ITRI & 5 \\
\hline Mound Plant & 4 \\
\hline Oak Ridge National Laboratory, $\mathrm{X}-10$ & 2 \\
\hline Paducah Gaseous Diffusion Plant & 1 \\
\hline Pantex Plant & 9 \\
\hline Pinellas Plant & 6 \\
\hline Portsmouth Gaseous Diffusion Plant & 1 \\
\hline Princeton Plasma Physics Lab & 8 \\
\hline Reynolds Electrical and Engineering Company, Inc. & 5 \\
\hline Sandia National Laboratories - Alb & 13 \\
\hline Sandia National Laboratories - Livermore & 13 \\
\hline Savannah River & 5 \\
\hline Stanford Linear Accelerator Center & 19 \\
\hline Tonopah Test Range & 3 \\
\hline Waste Isolation Pilot Plant - Carlsbad & 3 \\
\hline West Valley Demonstration Project & 4 \\
\hline$\widehat{Y-12}$ & 2 \\
\hline Total Contractual Usages & 238 \\
\hline
\end{tabular}




\begin{tabular}{|c|c|}
\hline SITE NAME & $\begin{array}{c}\text { Number of Unique } \\
\text { TSDFs Used }\end{array}$ \\
\hline Ames Laboratory - lowa State & 2 \\
\hline Argonne National Laboratory - East & 14 \\
\hline Battelle Pacific Northwest Labs & 1 \\
\hline Bettis Atomic Power Lab & 8 \\
\hline Brookhaven National Laboratory & 9 \\
\hline EG\&G - Los Alamos & 1 \\
\hline EG\&G Energy Measurements & 4 \\
\hline EG\&G Rocky Flats & 6 \\
\hline Fermi Lab & 16 \\
\hline Fernald Environmental Management & 6 \\
\hline Hanford & 6 \\
\hline Idaho National Engineering Laboratory & 11 \\
\hline K-25 Site & 1 \\
\hline Kansas City Plant & 11 \\
\hline Knolls Atomic Power Lab - Kesselring Site & 6 \\
\hline Knolls Atomic Power Lab - Schenectady & 4 \\
\hline Knolls Atomic Power Lab - Windsor Site & 8 \\
\hline Lawrence Berkeley Laboratory & 16 \\
\hline Lawrence Livermore National Laboratory & 28 \\
\hline Los Alamos National Laboratory & 10 \\
\hline Lovelace ITRI & 6 \\
\hline Mound Plant & 3 \\
\hline Oak Ridge National Laboratory, $X-10$ & 3 \\
\hline Paducah Gaseous Diffusion Plant & 2 \\
\hline Pantex Plant & 10 \\
\hline Pinellas Plant & 1 \\
\hline Portsmouth Gaseous Diffusion Plant & 1 \\
\hline Princeton Plasma Physics Lab & 9 \\
\hline Reynolds Electrical and Engineering Company, Inc. & 3 \\
\hline Sandia National Laboratories - Alb & 13 \\
\hline Sandia National Laboratories - Livermore & 15 \\
\hline Savannah River & 3 \\
\hline Stanford Linear Accelerator Center & 15 \\
\hline Waste Isolation Pilot Plant - Carlsbad & 5 \\
\hline West Valley Demonstration Project & 7 \\
\hline $\mathrm{Y}-12$ & 1 \\
\hline TOTAL & 265 \\
\hline
\end{tabular}




\begin{tabular}{|l|c|}
\hline \multicolumn{1}{|c|}{ SITE NAME } & $\begin{array}{c}\text { Number of Unique } \\
\text { TSDFs Used }\end{array}$ \\
\hline Ames Laboratory - lowa State & 3 \\
\hline Argonne National Laboratory - East & 7 \\
\hline Battelle Pacific Northwest Labs & 2 \\
\hline Bettis Atomic Power Lab & 2 \\
\hline Brookhaven National Laboratory & 11 \\
\hline Colonie Interim Storage Site & 2 \\
\hline EG\&G Energy Measurements & 5 \\
\hline EG\&G Rocky Flats & 6 \\
\hline Fermi Lab & 14 \\
\hline Fernald Environmental Management & 3 \\
\hline Hanford & 6 \\
\hline Idaho National Engineering Laboratory & 11 \\
\hline K-25 Site & 7 \\
\hline Kansas City Plant & 11 \\
\hline Knolls Atomic Power Lab - Kesselring Site & 6 \\
\hline Knolls Atomic Power Lab - Schenectady & 7 \\
\hline Knolls Atomic Power Lab - Windsor Site & 3 \\
\hline Lawrence Berkeley Laboratory & 15 \\
\hline Lawrence Livermore National Laboratory & 25 \\
\hline Los Alamos National Laboratory & 11 \\
\hline Lovelace ITRI & 9 \\
\hline Mound Plant & 5 \\
\hline Oak Ridge National Laboratory, X-10 & 4 \\
\hline Paducah Gaseous Diffusion Plant & 2 \\
\hline Pantex Plant & 8 \\
\hline Portsmouth Gaseous Diffusion Plant & 2 \\
\hline Princeton Plasma Physics Lab & 8 \\
\hline Reynolds Electrical and Engineering Company, Inc. & 7 \\
\hline Sandia National Laboratories - Alb & 13 \\
\hline Sandia National Laboratories - Livermore & 11 \\
\hline Savannah River & 4 \\
\hline Stanford Linear Accelerator Center & 15 \\
\hline U.S. Department of Energy & 2 \\
\hline Waste Isolation Pilot Plant - Carlsbad & 4 \\
\hline West Valley Demonstration Project & 7 \\
\hline Y-12 & 261 \\
\hline & \\
\hline
\end{tabular}




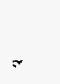

